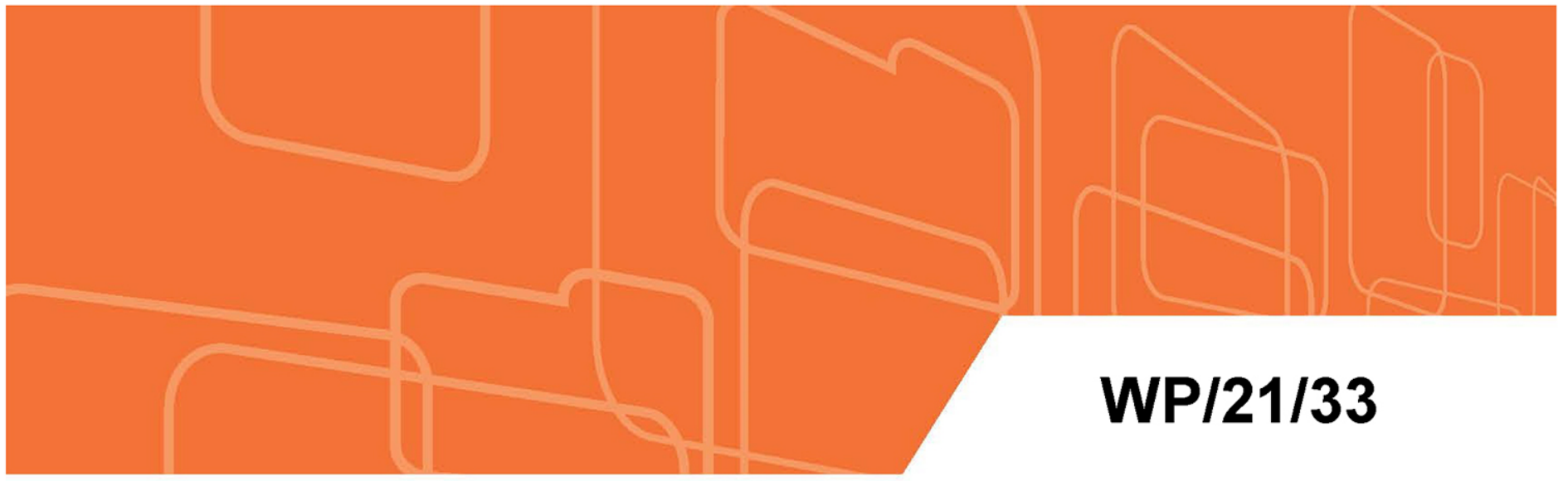

IMF Working Paper

\title{
Capital Markets, COVID-19 and Policy Measures
}

by Khalid EIFayoumi and Martina Hengge

IMF Working Papers describe research in progress by the author(s) and are published to elicit comments and to encourage debate. The views expressed in IMF Working Papers are those of the author(s) and do not necessarily represent the views of the IMF, its Executive Board, or IMF management. 


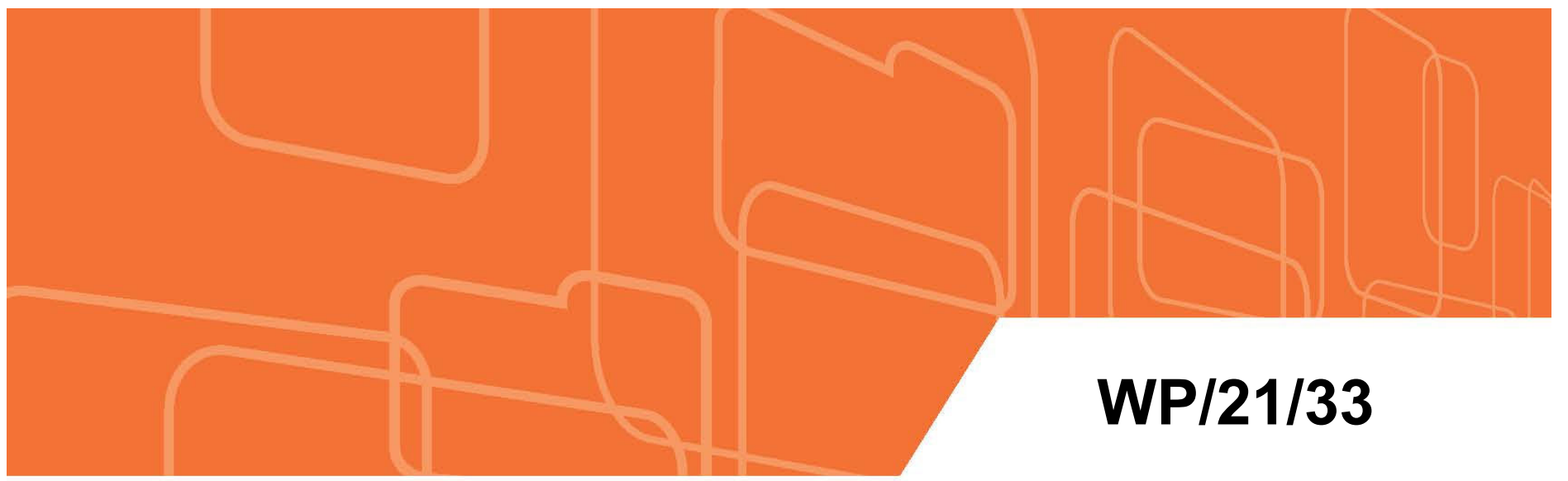

\section{IMF Working Paper}

\section{Capital Markets, COVID-19 and Policy Measures}

by Khalid EIFayoumi and Martina Hengge

IMF Working Papers describe research in progress by the author(s) and are published to elicit comments and to encourage debate. The views expressed in IMF Working Papers are those of the author(s) and do not necessarily represent the views of the IMF, its Executive Board, or IMF management. 


\title{
IMF Working Paper
}

\author{
European Department
}

\section{Capital Markets, COVID-19 and Policy Measures}

Prepared by Khalid ElFayoumi and Martina Hengge

Authorized for distribution by Miguel Segoviano

February 2021

\begin{abstract}
IMF Working Papers describe research in progress by the author(s) and are published to elicit comments and to encourage debate. The views expressed in IMF Working Papers are those of the author(s) and do not necessarily represent the views of the IMF, its Executive Board, or IMF management.
\end{abstract}

\begin{abstract}
The COVID-19 pandemic and associated policy responses triggered a historically large wave of capital reallocation between markets and asset classes. Using high-frequency country-level data, this paper examines if and how the number of COVID cases, the stringency of the lockdown, and the fiscal and monetary policy response determined the dynamics of portfolio flows. Despite more dominant global factors, we find that these domestic factors played an important role, particularly for emerging markets and bond flows, contributing to a global wave of reallocation to safer asset classes. Our results indicate that rising domestic COVID cases had a strong positive effect on portfolio flows, which responded to an increase in financing needs in affected economies. Lockdown and fiscal policy measures also led to an increase in portfolio flows; however, evidence from the CDS market suggests that the increase in flows was dominated by supply forces, reflecting investors' preference for stronger policy responses. In contrast, we find that interest rate cuts led to a decline in portfolio flows as investors searched for higher yield. Finally, we show that COVID policy responses also affected countries' exposure to the global shock and that pre-COVID macroeconomic conditions, such as lower sovereign risk and higher trade openness, contributed to larger flows during the COVID episode.
\end{abstract}

JEL Classification Numbers: F3, F21, G11

Keywords: Capital flows; COVID-19; Lockdown policy; Fiscal policy; Monetary policy; Pull factors; Emerging markets

Author's E-Mail Address: kelfayoumi@imf.org; mhengge@,imf.org 


\title{
Capital Markets, COVID-19 and Policy Measures*
}

\author{
Khalid ElFayoumi ${ }^{1}$ and Martina Hengge ${ }^{2}$ \\ ${ }^{1}$ International Monetary Fund \\ ${ }^{2}$ International Monetary Fund
}

\begin{abstract}
The COVID-19 pandemic and associated policy responses triggered a historically large wave of capital reallocation between markets and asset classes. Using high-frequency country-level data, this paper examines if and how the number of COVID cases, the stringency of the lockdown, and the fiscal and monetary policy response determined the dynamics of portfolio flows. Despite more dominant global factors, we find that these domestic factors played an important role, particularly for emerging markets and bond flows, contributing to a global wave of reallocation to safer asset classes. Our results indicate that rising domestic COVID cases had a strong positive effect on portfolio flows, which responded to the increase in financing needs. Lockdown and fiscal policy measures also led to an increase in portfolio flows; however, evidence from the CDS market suggests that the increase in flows was dominated by supply forces, reflecting investors' preference for stronger policy responses. In contrast, we find that interest rate cuts led to a decline in portfolio flows as investors searched for higher yield. Finally, we show that COVID policy responses also affected countries' exposure to the global shock and that preCOVID macroeconomic conditions, such as lower sovereign risk and higher trade openness, contributed to larger flows during the COVID episode.
\end{abstract}

JEL Classification: F3, F21, G11

Keywords: Capital flows; COVID-19; Lockdown stringency; Fiscal policy; Monetary policy; Pull factors; Emerging markets

\footnotetext{
${ }^{*}$ The views expressed herein are those of the authors and should not be attributed to the IMF, its Executive Board, or its management. We thank Klakow Akepanidtaworn, Cian Allen, Katharina Bergant, Nigel Chalk, Şebnem KalemliÖzcan, Robin Koepke, Simon Paetzold, Miguel Segoviano, Can Sever, Cédric Tille, and IMF WHD and EUR seminars participants for their comments and suggestions. All errors are our own. Email addresses: kelfayoumi@imf.org, mhengge@imf.org.
} 


\section{Introduction}

Compounding the global recession triggered by the COVID-19 pandemic, the worldwide health emergency also spurred a dramatic response in international capital markets. As investors gauged the economic consequences of the pandemic and the subsequent policy responses, they initiated a wave of capital reallocation between markets and asset classes. Using high-frequency weekly data of country-level portfolio flows, figure 1 highlights two notable facts about this wave. First, the global shift in international portfolio flows was of historically large magnitude. Second, countries' experience at the height of the episode differed widely.

This heterogeneity suggests that domestic pull factors have played an important role, both directly and indirectly via their impact on countries' sensitivity to the global shock. Unlike earlier risk-off events, such as the global financial crisis and the taper tantrum, which were largely driven by a global external shock (among others, Avdjiev et al., 2020; Fratzscher, 2012; Rey, 2015), the COVID-19 episode had a large domestic component due to the disruption it caused to local economic activity. Against this background, the question arises as to whether individual countries' handling of the crisis contributed to shaping the differing dynamics of portfolio flows.

Figure 1: Densities of portfolio flows (percent of allocation)

GFC (2008)

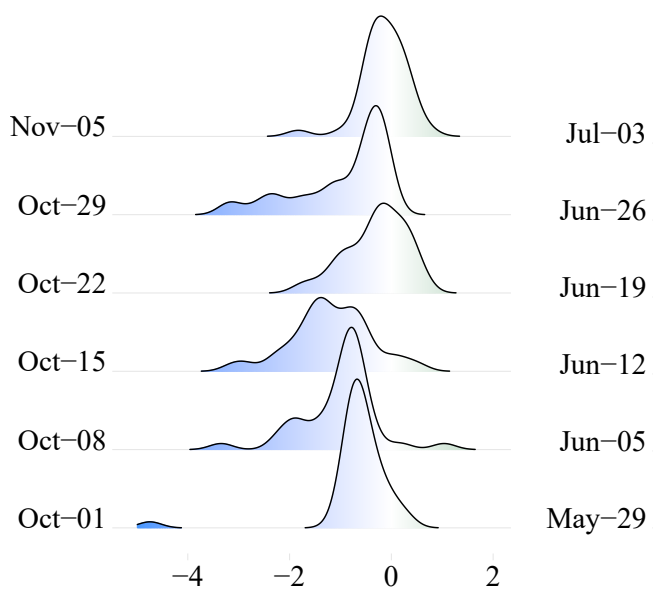

Taper tantrum (2013)
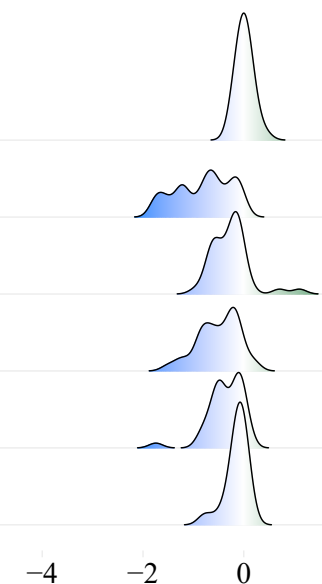

$-4$

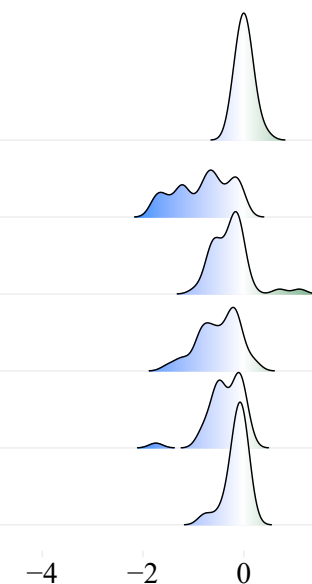

COVID-19 (2020)

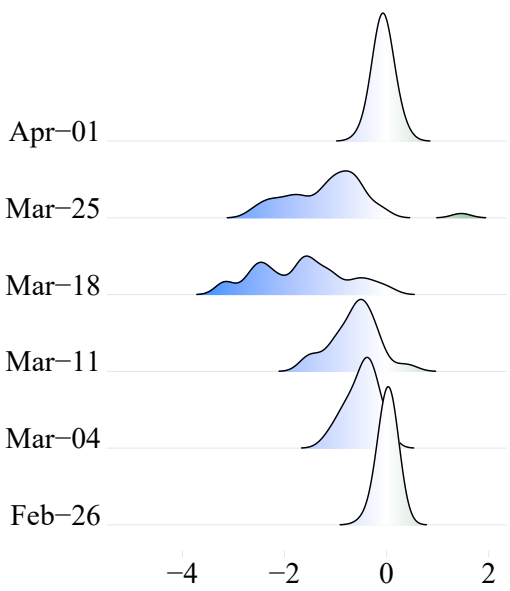

Notes: The horizontal axis shows total portfolio flows for all countries in our sample scaled by the allocation in the respective week.

In this paper, we address this question by evaluating international capital markets' response to countries' success, or lack thereof, in containing the pandemic and the key policy measures that governments enacted to limit the toll on public health and the economy. More specifically, we examine if and how the number of infections, the stringency of the lockdown, and the fiscal and monetary policy response determined the magnitude of portfolio flows and market-implied sovereign risk during the COVID-19 pandemic. To the best of our knowledge, this work is the first empirical contribution on the drivers of capital flows during the COVID-19 pandemic and their impact on 
sovereign financial stress.

A priori, the effect of these policies on capital markets is ambiguous. On the one hand, stringent lockdown measures are detrimental to economic activity. Aggressive fiscal spending and monetary policy actions eliminate policy buffers and may raise concerns about the sustainability of sovereign debt and the stability of inflation and the exchange rate, especially in emerging markets. On the other hand, these policies also signal a less prolonged recession and therefore higher returns in the medium term.

Our empirical strategy relies on a dynamic local projections approach to estimate both the contemporaneous and the cumulative response of capital markets to the severity of the pandemic and key policy measures. We collect a high-frequency dataset of portfolio flows and spreads of sovereign credit default swaps (CDS) for 37 countries over the first week of January 2014 to the second week of May 2020. Our identification strategy relies on the high frequency of the data and the efficiency by which investors' portfolios adjust to new market information. Both elements, as we discuss extensively below, allow us to overcome the inherent endogeneity between the spread of the virus, policy actions, and market outcomes.

Combined, information about the quantity (flows) and price (CDS spreads) of assets provides an identification of the supply and demand channels of portfolio flows. To the extent that these two measures are tightly linked by market forces, shifts in supply are associated with changes in flows and spreads in opposite directions, whereas shifts in demand move both variables in the same direction. $^{1}$ In addition, we explore three sources of heterogeneity based on market development (emerging markets (EMs) vs. developed markets (DMs)), asset class (bond vs. equity flows), and investors' domicile (foreign vs. domestic).

Overall, our findings demonstrate that capital market dynamics were not exclusively driven by undiscriminating global factors. Instead, the severity of the pandemic at the domestic level and governments' policy responses played a role in explaining the heterogeneity of portfolio flows and sovereign risk across countries during the COVID episode. ${ }^{2}$ With the exception of monetary policy, the empirical evidence suggests that the effects were particularly strong in EMs compared to DMs. There was also heterogeneity between the responses of domestic and foreign investors, which resulted in lower domestic allocations relative to foreign allocations.

Four takeaways are particularly salient. First, we find that the domestic spread of the virus in EMs led to a cumulative increase in total net flows over the one-month horizon ${ }^{3}$. This increase was associated with a reallocation towards safety as equity holdings declined and net bond flows rose. Sovereign CDS spreads increased, suggesting that the increase in net portfolio flows was driven by demand for liquidity, potentially reflecting widening financing needs to mitigate the fallout from

\footnotetext{
${ }^{1}$ Identification by sign restrictions is common in the time series VAR litertaure (Kilian and Lütkepohl, 2017). Gilchrist and Zakrajšek (2012) is another empirical example that looks into the relative contribution of credit supply and demand factors in corporate bond spreads.

${ }^{2}$ This finding is consistent with Kalemli-Özcan (2019) who shows that EM capital flows are particularly sensitive to country-specific risk sentiment, which is, in turn, determined by countries' policy credibility.

${ }^{3}$ Total net flows are defined as the net value of purchases and redemptions of bond and equity funds. Section 2 provides further details.
} 
the pandemic.

Second, EM governments' efforts to enact lockdown measures and provide fiscal stimulus were successful in supporting higher cumulative portfolio flows to the domestic economy. Unlike for COVID infection shocks, larger net portfolio flows in response to stricter lockdown measures were accompanied by a negative response of sovereign CDS spreads. This finding indicates that the impact of the lockdown was driven by an increased supply of financing, amidst stronger global demand for safer investment opportunities.

Third, we find that loosening policy rates in DMs, relative to the United States, triggered an increase in net portfolio flows upon impact; that is, central bank actions provided reassurance to markets, thereby stimulating flows to the domestic economy. Over the horizon of a month, however, we find that monetary policy cuts led to a decline in net portfolio flows, as expected by the interest rate parity and search for yield channels. This finding concurs with that in Fratzscher et al. (2018) who report a similar pattern in response to U.S. quantitative easing policies in the aftermath of the financial crisis. In contrast, we do not find a significant contemporaneous impact of a rate cut on portfolio flows in EMs. Cumulatively, however, flows declined in response to a more accommodative monetary policy stance, albeit to a smaller degree than for DMs.

Forth, despite the significant and sizeable role of domestic COVID factors, a historical decomposition analysis suggests that global factors played the larger role in explaining portfolio flow movements during the COVID episode. Their effect was negative and orders of magnitude larger in comparison to the COVID-related domestic factors, especially during the early and most uncertain phase of the pandemic. This large difference in magnitude between global and domestic COVID factors also suggests that other county-specific policy and institutional factors were responsible for why the net historical effect on portfolio flows in EMs was not as negative as the estimated contribution of global shocks during the pandemic would suggest.

Having documented the direct effect of countries' domestic actions on portfolio flows during the COVID episode, we extend our analysis to discuss their interaction with the global shock. Our findings indicate that stricter lockdown measures and expansionary monetary policy actions helped mitigate the negative impact of the global shock on portfolio flows. In contrast, while fiscal policy measures had a positive direct effect, we find that they exacerbated the impact of the global shock cumulatively, despite an initial positive effect. We interpret this less expected finding in light of the negative effect of fiscal stimulus on public debt sustainability, which appears to have adversely contributed to the global wave of portfolio reallocation triggered by the pandemic. ${ }^{4}$

Finally, we step back from evaluating immediate policy responses and explore if domestic preCOVID macroeconomic conditions and policy space indicators drove the portfolio flow response during the pandemic. On the fiscal side, we find that sovereign risk, not the deficit or the stock of debt, was the detrimental factor in differentiating the response of portfolio flows. Countries with higher sovereign default risk, i.e. higher CDS spreads, experienced a stronger decline in flows.

\footnotetext{
${ }^{4}$ An alternative explanation may suggest a potential dependency between the size of the fiscal stimulus and countries' exposure to external and global fluctuations, whereby countries that expected a larger downturn had to spend more early on. However, the country fixed effects in our specification control for such channels.
} 
Conditioning on this factor, government deficit had a statistically insignificant role and the economic significance of public debt was quite small in magnitude. With respect to the external sector, we find that the decline in flows was less severe in economies that enjoyed larger pre-COVID trade, reflecting investors' perception that more open economies could cushion the shock to domestic demand through their larger external sector. While trade openness was an important factor, the current account position was not, especially as we condition on the size of reserves, which had a significant positive effect.

This paper contributes to several strands of literature. We add to a large body of research on the drivers of international capital flows. Work by Forbes and Warnock (2011), Milesi-Ferretti et al. (2011), Fratzscher (2012), Sarno et al. (2016), and Davis et al. (2019) highlight that push factors, reflecting global conditions, are important determinants of capital flows. Milesi-Ferretti et al. (2011) and Fratzscher (2012), among others, also find an important role for domestic pull factors in driving flows. Fratzscher (2012) - perhaps the closest paper to ours - shows that domestic pull factors determined capital flows during the 2007-2009 global financial crisis and the subsequent recovery, in particular through their impact on the sensitivity to the global crisis event. For most countries, the COVID-19 pandemic combines a global risk-off episode with a large domestic shock. In this paper, we show that exposure to the pandemic and policy actions drove portfolio flows both directly and indirectly through their sensitivity to the global shock.

Our paper also relates to an emergent literature on the COVID-19 pandemic and its effect on financial markets. Chari et al. (2020) quantify the change in the distribution of EM portfolio flows during the COVID-19 risk-off shock and show that median flows declined in response to the shock. Alfaro et al. (2020), find that the severity of the pandemic predicts equity market returns in the U.S. An increase in infections is associated with large and negative swings in equity prices. Likewise, a study by Esteves and Sussman (2020) demonstrates that greater exposure to the pandemic penalizes EMs through an increase in sovereign bond spreads whereas OECD economies are not affected. Our analysis complements these studies by investigating the effect of the pandemic and key policy measures on portfolio flows and financial stress, as measured by CDS spreads.

The remainder of this paper is organized as follows. In section 2, we describe the data and present a set of stylized facts about portfolio flows and policy measures during the COVID-19 pandemic. Section 3 lays out the empirical strategy while section 4 presents our results. Section 5 summarizes our conclusions.

\section{Portfolio flows, the pandemic, and policy measures}

\subsection{Portfolio flows}

Our analysis uses data on weekly portfolio flows from EPFR Global. Flows are measured as the US $\$$ net value of purchases and redemptions into investment funds. ${ }^{5}$ Most of the funds covered by

\footnotetext{
${ }^{5}$ At the fund level, EPFR flows fully account for valuation effects due to asset returns and exchange rate movements. To compute flows at the country level, EPFR adds flows from single-country funds to flows from global/regional funds. While all flows data account for valuation effects, the country allocation data applied to global/regional funds
} 
EPFR are domiciled in DMs. Net injections into funds thus largely reflect international portfolio decisions of DM investors in EMs and other DMs. We opt to use EPFR portfolio flows in our analysis due to their high frequency, allowing us to identify the effects of the pandemic and other policy measures on portfolio flows. Another advantage of the data is their granularity - with information on the asset class and domicile - and the broad geographic coverage: our sample includes 21 DMs and 16 EMs over January 2014 to May 2020. ${ }^{6}$ Table A.1 in appendix A provides an overview of the market classification for each country in our sample. It is important to note that we interpret EPFR flows as a proxy for investment fund flows rather than the universe of portfolio flows. ${ }^{7}$

We document three stylized facts on net portfolio flows during the pandemic. First, portfolio outflows were of a historically large magnitude. Figure 2 highlights the dynamics of cumulative net portfolio flows to both DMs and EMs during three episodes of capital outflows - the COVID-19 pandemic, the taper tantrum, and the global financial crisis. The pandemic has led to outflows that markedly exceeded those experienced during earlier episodes, with particularly large bond outflows. While net portfolio flows reversed sharply both in EMs and DMs, the latter saw flows recovering less than two months into the pandemic. Net flows to EMs, in contrast, continued to decline for a longer period of time. Interestingly, however, the the magnitude of the reversal in bond flows was historically unprecedented when flows are measured in US\$ but not when normalized by portfolio allocation (figure B.1 in appendix B).

Second, as shown in figure 1 in section 1, the size of portfolio outflows during the COVID episode was strongly heterogeneous across countries, as reflected in the wide distribution of flows. At the height of the crisis, the standard deviation of net portfolio flows as a share of allocation was 1.1 percent. A comparison with previous capital outflow episodes illustrates that the range of net flows was larger than during the taper tantrum and similar to the global financial crisis. $A$ priori, this pattern suggests that COVID-related domestic factors might have played an important role in driving investors' portfolio reallocation during the crisis either through their direct effect or indirectly through their impact on the sensitivity to the global shock.

Last, zooming in on flows by geographical allocation in figure 3, illustrates that the observed heterogeneity in net portfolio flows across countries and time was aligned with the geographical progression of the COVID pandemic: both DMs and EMs in Asia-Pacific started to experience

to calculate flows at the country level abstract from valuation effects.

${ }^{6}$ Our sample ends in the second week of May due to a change in the availability of the fiscal spending data which we obtained from the IMF. In the second half of May, the IMF switched from a weekly to biweekly information update on governments' policy measures for some of the countries in our sample. In addition, while COVID cases, lockdown stringency and the fiscal spending response take the value zero for most of the sample period, we still choose to use the longer sample available. The larger number of observations allows for a better identification of the effects of the COVID-related variables through (i) lowering the estimation uncertainty around the effects of the set of control variables and (ii) enabling a dynamic specification while limiting the Nickell bias. See section 3.

${ }^{7}$ As of September 2020, funds reporting weekly data covered about 74 percent and 70 percent of the global investment equity and bond fund industry, respectively, based on EFAMA and ICI industry figures. Despite EPFR's focus on fund flows, the literature has reasoned that EPFR flows provide a fairly close match with BoP portfolio flows (see Fratzscher et al., 2018; Jotikasthira et al., 2012; Miao and Pant, 2012). Likewise, Koepke and Paetzold (2020) find that EPFR flows have significant predictive power for BoP portfolio flows. 
Figure 2: Cumulative equity and bond flows (US\$ million)
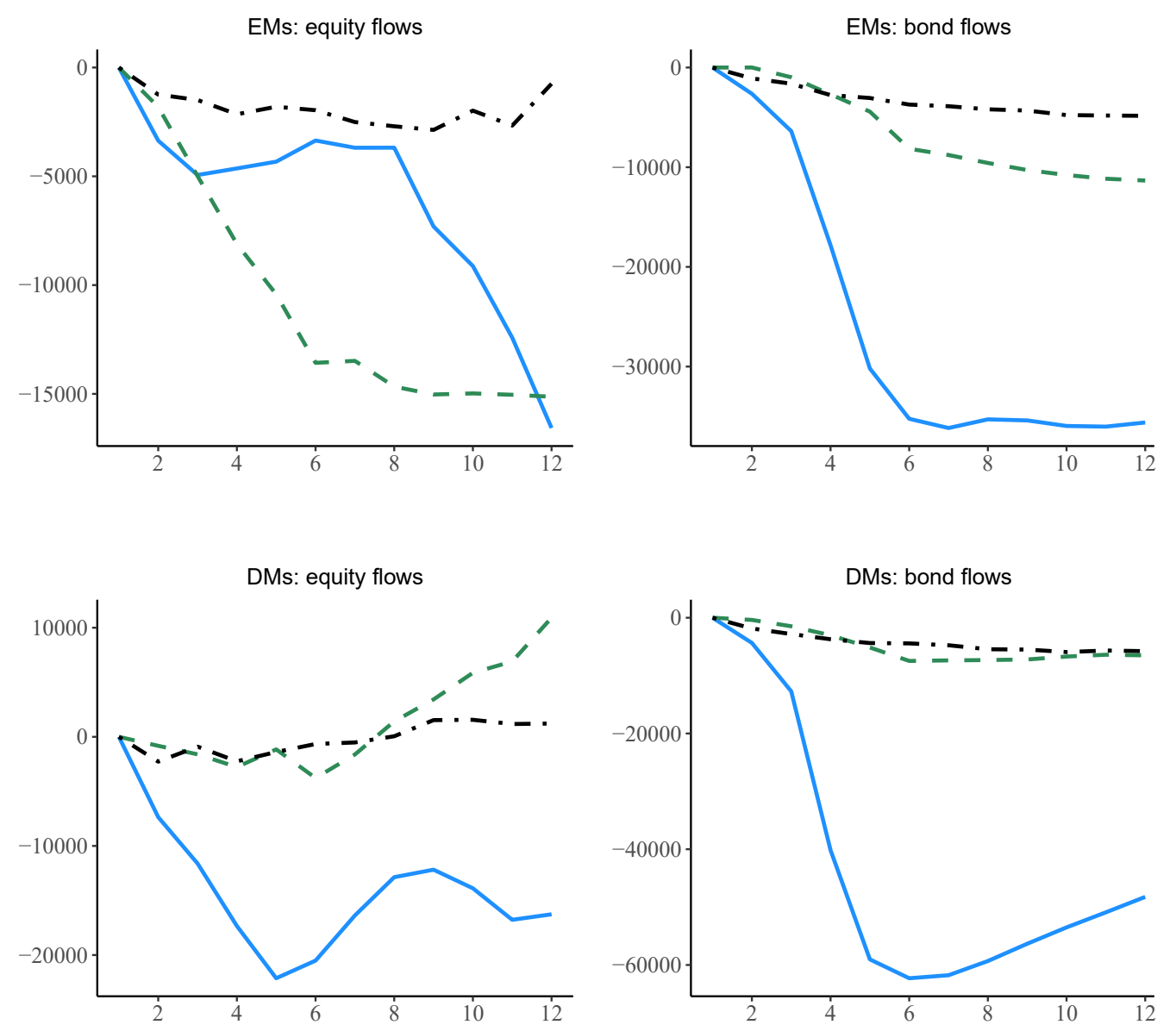

- COVID-19 - Taper tantrum - - GFC

Notes: $x$-axis shows weeks following the start date for the following episodes: COVID: 2020/02/26-2020/04/29; taper tantrum: 2013/05/22-2013/08/14; global financial crisis: 2008/10/08-2008/12/31. 
outflows in mid-February - earlier than other regions. Emerging Africa ${ }^{8}$ and Europe followed with net flows declining from the last week of February 2020 onward. Finally, EMs in the Americas and the Middle East as well as other DMs saw their initial outflows by the first week of March - one week before the WHO characterized COVID as a pandemic. With the virus having widely spread across the globe, net flows started to decline more sharply across all regions. Comparing the magnitudes of outflows across regions also highlights that measures to control the pandemic or mitigate the economic fallout might have affected investors' allocation decisions; outflows from Asia-Pacific were lower than outflows from other regions, such as the Americas, where governments' response was perceived less assertive. ${ }^{9}$

Figure 3: Cumulative equity and bond flows (percent of allocation)

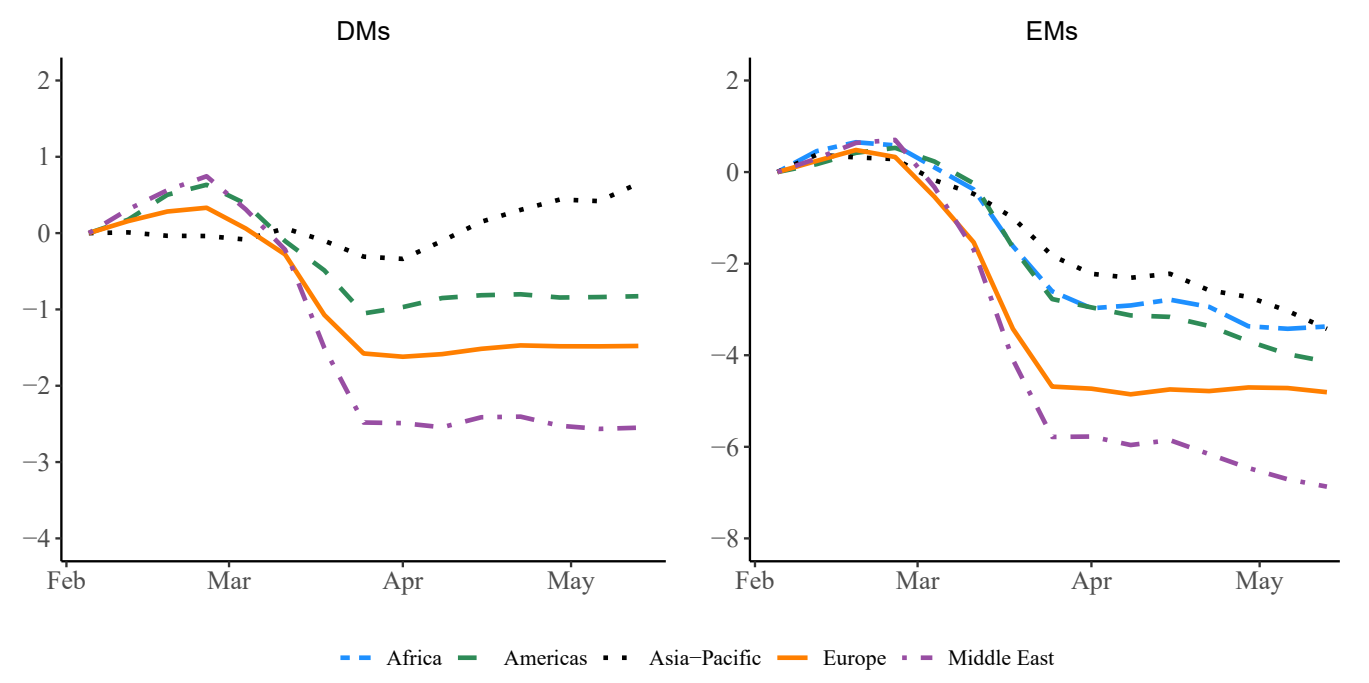

\subsection{COVID-19 and policy measures}

We study if the pandemic and policies implemented by governments around the world played a role in driving portfolio flows. The policy measures analyzed focus on containment measuresreflected in the stringency of the lockdown - as well as on macroeconomic stabilization trough fiscal and monetary policy. We collected data on COVID cases from Haver Analytics. Information on the stringency of the lockdown was obtained from Hale et al. (2020). This index measures the strictness of lockdown policies based on publicly available information. Data on the fiscal stimulus related to the pandemic are from the IMF's Survey on Country Responses which contains information on discretionary fiscal spending in response to the pandemic. Finally, we collected data on monetary policy rates from Haver Analytics and calculated the policy rate differential to the U.S. Fed Funds rate. In addition, we explore if the pandemic and its effect on portfolio flows also affected sovereign CDS spreads, using data from Bloomberg. Our analysis also controls for stock market returns, obtained from Haver Analytics.

\footnotetext{
${ }^{8}$ Emerging Africa represents South Africa, the only African country in our sample.

${ }^{9}$ Large outflows from the Middle East might also reflect the impact of the pandemic on the oil price collapse.
} 
Figure 4 shows the distribution of COVID cases and policy measures over January to May 2020. The markers represent the cross-country median and the vertical lines extend from the minimum to the maximum value across countries at each point in time. There was considerable heterogeneity of COVID cases and lockdown measures across countries and time. The number of cases (per 1,000 population) was more heterogeneous for DMs than EMs in March and April. As cases picked up, however, EMs were affected by the pandemic to a widely varying degree, as reflected in the large dispersion. The distribution of lockdown stringency shows that the average lockdown was relatively lenient until end-March both in DMs and EMs. In April, the average lockdown stringency increased sharply, suggesting that policymakers did not see much middle ground for containing the pandemic. In addition, the narrowing of the vertical lines as of April indicates that the lockdown response became more homogeneous as cases increased.

Policymakers also responded with vastly different macroeconomic stabilization measures. While fiscal spending in our sample - reflecting the first round of stimulus in most countries - was largely concentrated in the range up to 5 percent of GDP, some countries spent even more sizeable amounts to shield the economy. In contrast, policy rate differentials were relatively homogeneous for DMs, whereas they were more scattered for EMs, possibly reflecting limited ability to loosen monetary policy due to capital outflow pressures in some countries. Table 1 reports the summary statistics for COVID infections and policy measures.

Table 1: Summary statistics of COVID cases and policy measures

\begin{tabular}{lcccccc}
\hline Statistic & $\mathrm{N}$ & Mean & St. Dev. & Min & Median & Max \\
\hline Developed markets & & & & & & \\
COVID-19 cases (per 1000 pop.) & 357 & 0.7 & 1.2 & 0.0 & 0.1 & 5.0 \\
Lockdown stringency (0 to 100) & 357 & 44.3 & 33.2 & 0.0 & 45.8 & 96.0 \\
Fiscal spending (percent of GDP) & 100 & 4.6 & 3.1 & 1.1 & 3.9 & 11.2 \\
Policy rate differential (pp) & 357 & -0.6 & 0.8 & -2.4 & -0.1 & 1.6 \\
\hline Emerging markets & & & & & & \\
COVID-19 cases (per 1000 pop.) & 272 & 0.2 & 0.8 & 0.0 & 0.01 & 9.0 \\
Lockdown stringency (0 to 100) & 272 & 48.1 & 35.7 & 0.0 & 56.9 & 97.0 \\
Fiscal spending (percent of GDP) & 76 & 3.5 & 2.6 & 0.2 & 2.7 & 9.8 \\
Policy rate differential (pp) & 272 & 2.8 & 2.9 & -1.6 & 2.4 & 11.4 \\
\hline
\end{tabular}

Notes: Observations over 2020/01/22-2020/05/13. 
Figure 4: COVID-related controls
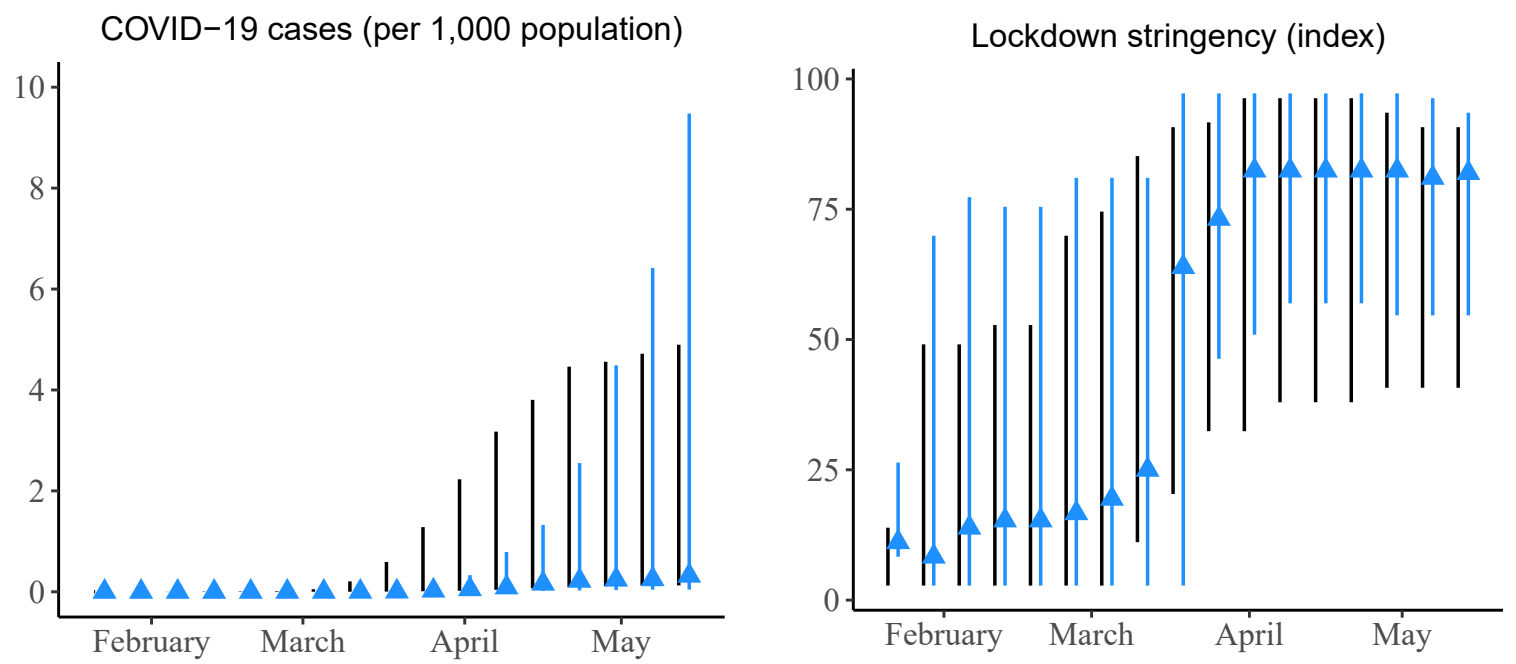

Fiscal spending (percent of GDP)
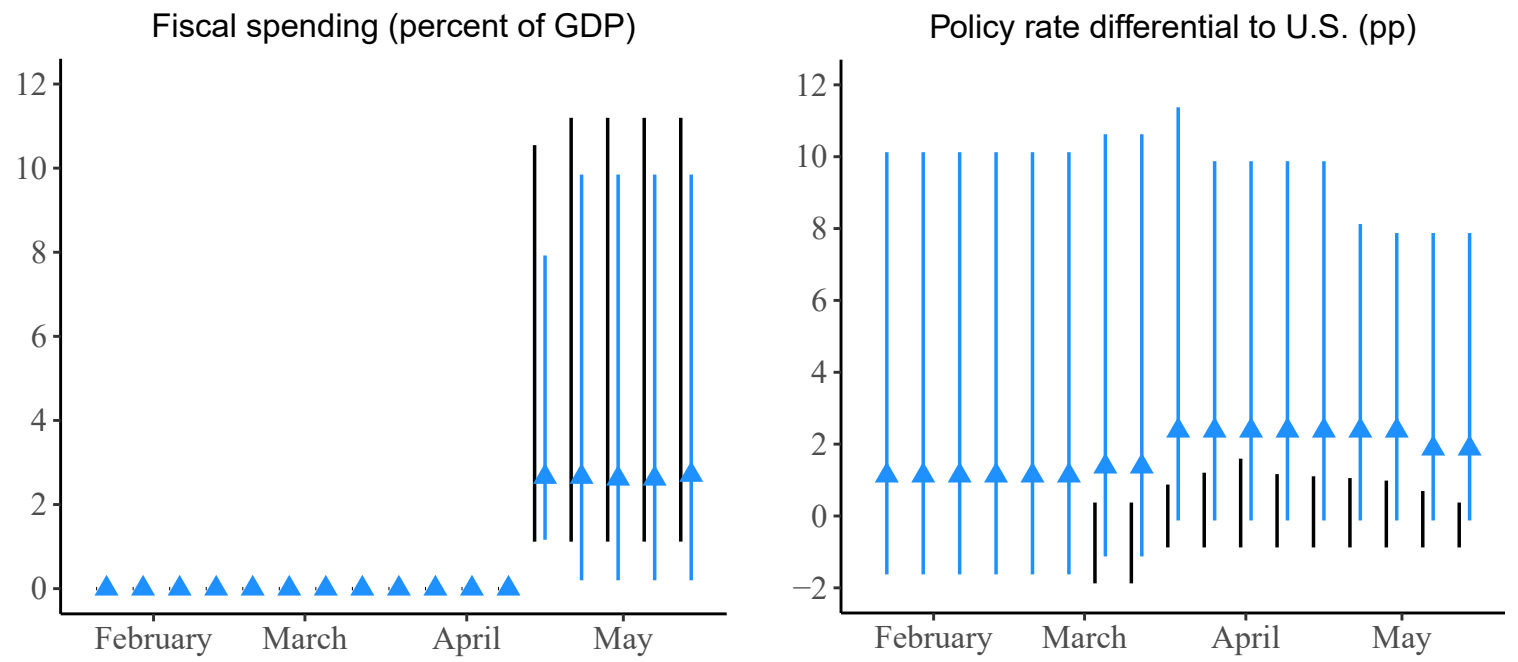

中 DMs 4 EMs

Notes: Observations over 2020/01/22-2020/05/13. The marker represents the cross-country median and the bars extend from the minimum to the maximum value across countries, respectively. 


\section{$3 \quad$ Empirical strategy}

The goal of the analysis is to empirically evaluate the impact of countries' exposure to the pandemic and the key policy measures that governments enacted on capital markets. We rely on the empirical specification in Fratzscher (2012) and Fratzscher et al. (2018) as a starting point for our analysis. We control for the expected component of portfolio flows and model the unexpected component as a function of both global and domestic factors. Our empirical specification allows for heterogeneity between countries (DMs and EMs), investors' domicile (foreign and domestic), and asset classes (bond and equity flows).

We stress two aspects of our empirical approach. First, we present a structural empirical specification. That is, we argue that the estimated coefficients capture the causal elasticities of our dependent capital market variables to the key identified (i.e. exogenous) COVID-related controls. Second, we explicitly model the endogeneity inherent in capital markets between portfolio flows, financial stress, and stock returns, which is essential to identify the mechanisms behind the estimated responses.

The linkage between these three main variables is developed in the theoretical framework of Caballero and Simsek (2020), which we rely on to guide our empirical analysis. Countries in the model are asymmetric with respect to both market liquidity and expected returns, and Caballero and Simsek (2020) explicitly distinguish between asset classes (risky and safe assets) and investors' domicile (foreign and domestic). The model therefore provides a structural foundation for some of the key patterns typically observed in the data (e.g. fickleness, retrenchment, reach for safety and reach for yield $)^{10}$, which we could contrast our empirical findings against.

\subsection{Empirical model}

We estimate the following baseline regression at a weekly frequency using the local projections approach (Jordà, 2005):

$$
\begin{aligned}
Y_{c, t+h}= & E_{t-1}\left\{Y_{c, t+h}\right\}+\beta_{1}^{h} \text { New COVID Cases }{ }_{c, t}+\beta_{2}^{h} \text { Lockdown }_{c, t}+\beta_{3}^{h} \text { Fiscal Stimulus }_{c, t}+ \\
& \beta_{4}^{h} \text { Policy Rate }_{c, t}+\beta_{5}^{h} \text { isCOVID }_{c, t}+\beta_{6}^{h} \text { Policy Rate }_{c, t} \times \text { isCOVID }_{c, t}+ \\
& \eta_{c}+\eta_{D M s, t+h}+\eta_{E M s, t+h}+\eta_{c} \times \eta_{m}+e_{c, t+h}
\end{aligned}
$$

where $Y_{c, t+h}$ represents net portfolio flows or sovereign CDS spreads in country $c$ at time $t+h$. We study the model dynamics over the horizon $h=0$ and cumulatively over $h=0, \ldots, 3$, whereby we estimate the cumulative effect by summing the dependent variable over the month, $\sum_{h=0}^{h=3} Y_{c, t+h}$. We choose to focus on sovereign CDS spreads as a measure of risk in the economy, given the large and dominant role of sovereign borrowing in EMs where private sector access to foreign borrowing may be limited (Avdjiev et al., 2020).

We scale net portfolio flows by their pre-COVID allocation to capture the dynamics of the average country in our sample. This scaling guarantees that the estimated coefficients are not

\footnotetext{
${ }^{10}$ See Broner et al. (2013) for empirical analysis of gross foreign and domestic flows over the business cycle and during financial crises.
} 
driven by a selected group of countries, given that the absolute value of portfolio flows depends on market size. Similar to the analysis in section 2 , we choose the allocation value reported for the week of February 26, 2020. Next, we scale the portfolio flows to allocation ratio by its standard deviation of the pre-COVID sample.

$E_{t-1}\left\{Y_{c, t+h}\right\}$ is the expected value of $Y_{c, t+h}$ using the information available at time $t-1$. To capture this expectation term, we use one lag of each of the following variables: ${ }^{11}$ portfolio flows, sovereign CDS spreads, stock market returns, the interest rate differential with the U.S., the total number of domestic COVID-19 cases, and log portfolio allocation. ${ }^{12}$

New COVID Cases captures the change in domestic COVID infections. We scale the new COVID cases by population ${ }^{13}$ to arrive at the number of new cases per capita, and scale the variable by its sample standard deviation. Since COVID cases are zero for the majority of our sample period, we only use non-zero values when calculating the standard deviation.

Lockdown is a lockdown stringency index, ranging over 0 to 100 , which we standardize to facilitate the interpretation of the estimates. Fiscal Stimulus captures COVID-related discretionary fiscal spending in percent of GDP, and Policy Rate is the difference between the policy rate of each country and the U.S. Given the absence of a comparable measure of unconventional monetary policy across the countries in our sample, we focus on the policy rate. isCOVID is a dummy variable that takes the value one for each country-week observation when the number of COVID cases is greater than zero, and zero otherwise. $\eta_{c}$ is a country fixed effect while $\eta_{D M s, t}$ and $\eta_{E M s, t}$ are week fixed effects for DMs and EMs, respectively, to allow for heterogeneity in the impact of global shocks across the two groups. $\eta_{c} \times \eta_{m}$ is a country $\times$ month fixed effect, which controls for all slow-moving domestic factors.

\subsection{Identification strategy}

Our identification strategy relies on three elements: first, the high (weekly) frequency of capital market data; second, the efficiency by which portfolio flows adjust to new market information as soon as it becomes available; third, the comprehensive set of controls and fixed effects that we include in our specification. We discuss below how these three elements combined allow us to identify the structural elasticities of the four COVID-related domestic factors we study.

COVID infections are driven by epidemiological factors that are mostly independent (i.e exogenous) of capital market outcomes and form a predictable trajectory for the pandemic. However, to the extent that past government crisis management measures (including lockdown and social distancing) contribute to this trajectory, an omitted variable concern arises as the estimated effect of new COVID cases on portfolio flows could be driven in part by market responses to past policies.

While this concern is valid for slow-moving market outcomes, adjustment in financial portfolios

\footnotetext{
${ }^{11}$ The large $T$ dimension of our sample ensures that the Nickell bias brought about by our dynamic specification is negligible (Nickell, 1981).

${ }^{12}$ Controlling for expected flows and the dynamic specification of the empirical model also help account for the fund flow-performance relationship, whereby fund flows are known to chase strong past performance (Berk and Green, 2004).

${ }^{13}$ We use population reported in the World Bank database for 2017 which is the last reported year for the whole world.
} 
tends to take place at a high pace, absorbing in the same period all available news about expected future developments, including the expected COVID trajectory. ${ }^{14}$ The implication is that the impact of past policy actions on current portfolio flows is expected to be of a limited magnitude. In addition, in the $E_{t-1} Y_{t}$ term on the right-hand side of our specification, we include lagged flows, their allocation, and more importantly domestic stock returns. These variables readily react to any new information that markets receive (shocks) about the expected trajectory of cases.

Finally, including country $\times$ month fixed effects controls for institutional variations that may influence the country's capacity to test and report up-to-date figures of COVID infections. Combined, these arguments allow us to maintain the assumption that the new COVID cases variable, conditional on the specification in equation 1, is exogenous to contemporaneous capital market events, and that its estimated effect captures the elasticity to COVID infection shocks.

For lockdown stringency as well as fiscal and monetary policy actions, identification relies on the fact that these measures are typically taken with a lag of more than one week in response to unexpected events and new information, because of the time governments and central banks need to reach these decisions. Hence, with the high frequency at which we observe portfolio flows, we can maintain the assumption that these measures are contemporaneously exogenous. Similar intuition motivates other work that uses EPFR data to study the impact of monetary policy actions for instance (Fratzscher et al., 2018).

Another concern arises in identifying the effects of the policy measures if the variations we observe in these measures are a result of endogenous responses to other past shocks. An example would be a past increase in the number of COVID cases that triggers a more stringent lockdown today, and a stronger fiscal stimulus in turn. Similar to the previous discussion, the $E_{t-1} Y_{t}$ term and the country $\times$ month fixed effects on the right-hand side of our specification both play an important role in mitigating this dynamic endogeneity, specifically the omitted variable, concern. The lagged number of COVID cases per capita controls for the degree of the spread of the virus. More importantly, the lagged capital market variables absorb past shocks that could drive an endogenous policy response. In addition to these sets of controls, the tight country $\times$ month fixed effects specification captures shocks to aggregate economic conditions and market activities that enter the objective function of government authorities and central banks. Similar intuition is shared by the growing literature on high-frequency identification methods with respect to monetary policy actions (Nakamura and Steinsson, 2018).

Following up on our example, if the reason a country has a more stringent lockdown policy at time $t$ is a surprise spike in the number of COVID cases at time $t-1$, then the endogenous increase in the lockdown stringency would be associated with a change in the lagged values of both

\footnotetext{
${ }^{14}$ We also implement and test our results against the approach followed in Alfaro et al. (2020) who distinguish between the expected and surprise components of new COVID cases using curve fitting methods. While our main results do not change, we believe that our identification is robust to this decomposition since the expected component of flows (as well as new COVID cases) is controlled for by the $E_{t-1}\left\{Y_{c, t+h}\right\}$ term. Given the degrees of freedom embedded in this curve fitting approach (that is, assumptions have to be made about multiple parameters to limit the number of possible trajectories of a country's COVID cases series), we opt for the transparent approach of taking the first difference of the number of COVID cases instead.
} 
stock returns and net flows in addition to a higher number of COVID cases per capita. All three are controlled for in our specification, allowing us to identify the causal effect of variations in the lockdown measures that are independent of other economic and pandemic-related developments. The same intuition holds for fiscal and monetary policy actions.

Finally, we include country fixed effects to control for time-invariant country-specific characteristics and week fixed effects to control for all global push factors. We also opt for a conservative specification and, as mentioned above, include country $\times$ month fixed effects to control for countryspecific institutional variations and slow-moving shocks related to changes in policies, such as capital controls, and aggregate economic developments.

\section{Results}

This section shows that heterogeneity in countries' exposure to the COVID-19 pandemic and related measures taken by governments played a significant role in determining the dynamics of portfolio flows and CDS spreads during the COVID episode. We present the results for the contemporaneous and cumulative dynamic effects using the local projections approach discussed in section 3 and analyze how the effects varied across DMs and EMs, bond and equity flows, and across foreign and domestic investors. In addition, we extend the analysis beyond the average effects of the domestic COVID-related factors and investigate the nonlinearities brought about by their interaction with global factors. Finally, we also explore the role that pre-existing macroeconomic fundamentals played in driving flows during the COVID episode.

\subsection{COVID-19 related domestic factors as drivers of portfolio flows}

We start our analysis by focusing on foreign-domiciled flows, that is, flows stemming from funds that are domiciled outside the recipient country. Table 2 demonstrates how the empirical estimates of the average effects on total net flows evolve as we tighten our model specification and add more controls, using all 37 countries in our sample. For each specification, we show the response of total net portfolio flows upon impact $(h=0)$ and the cumulative response over the one-month horizon $(h=0: 3)$ The first specification in columns 1 and 2 controls for COVID-related domestic factors, expected flows and country fixed effects. In columns 3 and 4, we add week fixed effects to control for global factors, whereby we allow for two independent time trends for DMs and EMs. Finally, we include country $\times$ month fixed effects in columns 5 and 6 to capture country-level slow-moving variations - such as balance sheet vulnerabilities and capital controls.

Comparing the results across these different specifications allows us to make two observations. First, the estimated coefficients on the domestic factors change considerably once we control for global factors through time fixed effects. These changes point at a common (i.e. global) component in the COVID-related domestic variables that masks their domestic effect if not controlled for. The second observation relates to the relatively large increase in the adjusted $R^{2}$ associated with

adding country $\times$ month fixed effects. It points at the importance of pull (i.e. domestic) factors in explaining contemporaneous variations in portfolio flows. 
In the remainder of this section, we focus on the most conservative specification, which controls for unobserved heterogeneity at the country level, global weekly shocks, and country-specific monthly shocks. As discussed in section 3, this combination of fixed effects is crucial to our identification. In addition, we control for expected net portfolio flows, measured as a function of lagged flows and other lagged determinants, including sovereign risk and domestic stock prices.

\section{COVID-19 cases}

We now turn to the response of portfolio flows to countries' exposure to the pandemic. According to the results in table 2, higher new domestic COVID cases per capita had an insignificant effect on portfolio flows upon impact (column 5). Over the one-month horizon (column 6), however, a one standard deviation increase in the number of new domestic COVID cases per capita was associated with a 1.13 standard deviation increase in foreign net portfolio flows (as a ratio of total allocation). As we detail below, disaggregating our sample by market (EMs vs. DMs) and asset class (bond vs. equity flows) indicates that the average positive effect was mainly driven by bond flows in EMs. In addition, our findings with respect to sovereign CDS spreads support the interpretation that an increase in COVID cases was associated with widening financing needs, which were met by foreign investors in the form of bond flows.

The cumulative response of net portfolio flows to an increase in new domestic COVID cases was positive in both DMs and EMs but was largely driven by the latter (table 2, column 8; figure 5). Looking at the response of equity and bond flows (table 3), we find that the average response of EM flows was determined by bond flows, in line with the stylized facts in section 2. Equity flows, in contrast, experienced a cumulative decline in both EMs and DMs. Interestingly, net bond flows declined upon impact of the COVID shock, suggesting that investors initially perceived higher COVID cases as bad news.

The results for sovereign CDS spreads (table 4) - a proxy for sovereign financing costs and aggregate risk when markets are efficient - suggests that demand for financing by affected economies

(i.e. a larger supply of bonds) was the dominant force behind the cumulative increase in bond flows, especially in EMs. We see this in the positive cumulative effect the domestic COVID shock has on both flows (i.e. quantity) and CDS spreads (i.e. price) for both country groups; a one standard deviation increase in the number of new COVID cases per capita was associated with a significant increase in the growth of CDS spreads by 0.18 percent in EMs and 0.03 percent in DMs, respectively, over the one-month horizon. As explained in section 1, the interpretation of this result relies on the intuition that an increase in bond flows together with a rise in the cost of risk and thus borrowing implies a shift in the 'demand for financing curve'.

\section{Lockdown measures}

The first policy measure governments took to address the pandemic was locking down the economy to contain the spread of the virus. A priori, it is ambiguous how markets weighed potential losses in economic activity against the possibility that stricter containment measures could imply a faster recovery. The results for the aggregate sample in table 2 (columns 5 and 6) show that a one standard deviation change in the stringency of the lockdown led to an increase in cumulative 
net portfolio flows by 0.32 standard deviations over a one-month horizon in the average country, after an initial decline.

Similar to the domestic COVID shock discussed above, the cumulative one-month increase was driven by EMs rather than DMs for which the response was insignificant (table 2, columns 7 and 8; figure 5). Interestingly, we find that China was the main determinant of the strong positive cumulative effect in EMs. China was one of the first countries that implemented a relatively strict lockdown, which enabled it to control the pandemic sooner compared to other countries and contributed to investors' confidence. This result is consistent with the theoretical framework in Çakmakli et al. (2020), which predicts that the economic cost due to the COVID-19 pandemic is lower under an effective full lockdown compared to a partial but longer one.

Table 3 also shows that the increase of foreign fund flows into EMs after the initial decline was dominated by bond flows, in line with a reallocation to safety pattern. In contrast, equity flows to EMs moved in the opposite direction, experiencing a significant decline. Importantly, unlike the effect of domestic infection shocks, our estimates (table 4) indicate that a stricter lockdown was associated with lower CDS spreads over the one-month horizon in EMs and DMs alike. Given the assumptions outlined above on the role of flows and CDS spreads in identifying supply and demand effects, this result implies that an increase in lockdown measures triggered increased demand from EM investors, especially for safer assets.

\section{Discretionary fiscal stimulus}

Another key policy component of governments' response packages was large fiscal stimulus, implemented across the majority of countries in our sample. As we discussed in section 3 , the expected impact of fiscal spending on markets is ambiguous due to a trade-off between positive demand effects and potentially negative fiscal sustainability implications. The results in table 2 (columns 5 and 6) for the average country show that although the impact of fiscal stimulus was negative initially, over the horizon of one month, an increase in fiscal spending was perceived as a positive policy measure, attracting portfolio flows to the economy.

Importantly, the effect was particularly strong in EMs (table 2, columns 7 and 8; figure 5). For every one percent increase in fiscal spending as a share of GDP, net flows increased by 1.65 standard deviations in EMs, compared to 0.33 standard deviations in DMs where fiscal measures appear to have been less relevant for foreign investors' appetite. The aggregate pattern holds for both bond and equity flows and remains primarily driven by EMs for both asset classes (table 3). The response in sovereign CDS spreads was not significant over the one-month horizon (table 4), thereby not providing an indication on the potential drivers of the increase in cumulative flows. ${ }^{15}$

\footnotetext{
${ }^{15}$ Many governments financed their stimulus spending through borrowing in international capital markets, suggesting that the estimated increase in flows following fiscal measures might partially reflect a mechanical effect. While we cannot directly quantify the relative share of the mechanical response (since the data do not allow us to observe the counter-party of the transaction), our findings indicate that the non-mechanical response, driven by an improved economic outlook, did play an important role. This observation shows in the finding that net equity flows, not only net bond flows, increased in response to the stimulus.
} 


\section{Discretionary monetary policy}

In addition to lockdown measures and fiscal spending, the majority of countries deployed monetary policy measures to stabilize the domestic economy. As explained in section 3, our highfrequency weekly data allow us to capture the effect of central banks' policy rate movements on portfolio flows while alleviating concerns about potential reverse causality. Given the absence of a comparable measure of unconventional monetary policy measure across a large sample of countries, we focus on the short-term policy rate.

We find that, on average, changes in the policy rate relative to the U.S. do not seem to have played a statistically significant role in the dynamics of portfolio flows (table 2, columns 5 and 6 ). This result applies over the full length of the sample as well as throughout the COVID episode. Comparing DMs and EMs over the full sample period (table 2, columns 7 and 8; figure 5), shows that the statistical insignificance of monetary actions in average portfolio flows dynamics is driven by EMs. We interpret this finding in light of the dilemma hypothesis (Rey, 2015), which suggests that U.S. financial dominance renders EM monetary policy ineffective against market fluctuations.

Notably however, EM monetary policy played a role in driving portfolio flows during the COVID episode (table 2, columns 7 and 8). A hundred basis points cut in the interest rate led to a cumulative decline in net portfolio flows by 0.21 standard deviations while the response was not significant upon impact of the shock. For DMs, a hundred basis points cut in the interest rate was associated with an increase in net flows by 0.64 standard deviations upon impact of the shock, suggesting that central bank actions initially had a reassuring effect on markets. Cumulatively, however, a monetary policy cut led to a decline in net portfolio flows in DMs, whereby the response was even larger than in EMs.

Zooming in on the response by asset class (table 3) shows that the negative cumulative impact of a lower policy rate was driven by different factors in EMs and DMs. In EMs, the decline in total net portfolio flows was entirely driven by bond flows, in line with interest rate parity. In DMs, in contrast, both bond and equity flows responded negatively to a rate cut, with a larger elasticity for equity flows.

Table 4 indicates that expansionary EM monetary policy was associated with an increase in CDS returns during the COVID episode (3.14 percent increase for every hundred basis point cut in the policy rate). Although CDS returns increased largely only upon impact, these findings are not consistent with the classical credit channel effects of monetary policy on risk spreads. In this respect, the information channel of monetary policy Nakamura and Steinsson (2018) could offer an alternative explanation, whereby aggressive rate cuts during the pandemic could have temporarily fueled markets' concerns about the expected fallout from the pandemic. 
Table 2: The effect of domestic COVID factors on total flows (foreign domicile)

\begin{tabular}{|c|c|c|c|c|c|c|c|c|}
\hline & $\begin{array}{c}(1) \\
\mathrm{h}=0\end{array}$ & $\begin{array}{c}(2) \\
\operatorname{cum}(\mathrm{h}=0: 3)\end{array}$ & $\begin{array}{c}(3) \\
\mathrm{h}=0\end{array}$ & $\begin{array}{c}(4) \\
\operatorname{cum}(\mathrm{h}=0: 3)\end{array}$ & $\begin{array}{c}(5) \\
h=0\end{array}$ & $\begin{array}{c}(6) \\
\operatorname{cum}(\mathrm{h}=0: 3)\end{array}$ & $\begin{array}{c}(7) \\
\mathrm{h}=0\end{array}$ & $\begin{array}{c}(8) \\
\operatorname{cum}(\mathrm{h}=0: 3)\end{array}$ \\
\hline New Covid $\operatorname{cases}_{c, t}$ & $\begin{array}{l}0.09^{* *} \\
(0.04)\end{array}$ & $\begin{array}{l}0.47^{* * *} \\
(0.13)\end{array}$ & $\begin{array}{c}-0.31^{* * *} \\
(0.03)\end{array}$ & $\begin{array}{l}0.17^{* *} \\
(0.08)\end{array}$ & $\begin{array}{c}0.01 \\
(0.05)\end{array}$ & $\begin{array}{l}1.13^{* * *} \\
(0.07)\end{array}$ & $\begin{array}{c}-0.02 \\
(0.05)\end{array}$ & $\begin{array}{l}3.81^{* * *} \\
(0.47)\end{array}$ \\
\hline Lockdown stringency $_{c, t}$ & $\begin{array}{l}0.12^{* * *} \\
(0.04)\end{array}$ & $\begin{array}{l}2.50^{* * *} \\
(0.39)\end{array}$ & $\begin{array}{c}-0.56^{* * *} \\
(0.09)\end{array}$ & $\begin{array}{c}0.04 \\
(0.21)\end{array}$ & $\begin{array}{c}-0.82^{* * *} \\
(0.15)\end{array}$ & $\begin{array}{c}0.32^{* *} \\
(0.16)\end{array}$ & $\begin{array}{c}-0.47^{* * *} \\
(0.07)\end{array}$ & $\begin{array}{l}1.15^{* * *} \\
(0.22)\end{array}$ \\
\hline Fiscal stimulus $_{c, t}$ & $\begin{array}{c}-0.06^{* * *} \\
(0.01)\end{array}$ & $\begin{array}{c}-0.39^{* * *} \\
(0.04)\end{array}$ & $\begin{array}{c}0.03 \\
(0.02)\end{array}$ & $\begin{array}{r}0.05^{*} \\
(0.03)\end{array}$ & $\begin{array}{c}-0.37^{* * *} \\
(0.05)\end{array}$ & $\begin{array}{l}0.35^{* * *} \\
(0.07)\end{array}$ & $\begin{array}{c}0.01 \\
(0.01)\end{array}$ & $\begin{array}{l}1.65^{* * *} \\
(0.45)\end{array}$ \\
\hline Policy rate r.t & $\begin{array}{c}-0.22 \\
(0.18)\end{array}$ & $\begin{array}{c}-0.79 \\
(0.48)\end{array}$ & $\begin{array}{c}-0.02 \\
(0.08)\end{array}$ & $\begin{array}{r}-0.10 \\
(0.09)\end{array}$ & $\begin{array}{c}-0.03 \\
(0.09)\end{array}$ & $\begin{array}{c}0.02 \\
(0.09)\end{array}$ & $\begin{array}{c}-0.01 \\
(0.08)\end{array}$ & $\begin{array}{c}-0.01 \\
(0.13)\end{array}$ \\
\hline isCOVID $_{c, t}$ & $\begin{array}{c}-0.89^{* * *} \\
(0.10)\end{array}$ & $\begin{array}{c}-6.96^{* * *} \\
(0.47)\end{array}$ & $\begin{array}{c}0.04 \\
(0.09)\end{array}$ & $\begin{array}{c}-0.49^{* * *} \\
(0.15)\end{array}$ & $\begin{array}{c}-0.17 \\
(0.12)\end{array}$ & $\begin{array}{c}-0.73^{* * *} \\
(0.15)\end{array}$ & $\begin{array}{c}0.08 \\
(0.08)\end{array}$ & $\begin{array}{c}-1.51^{* * *} \\
(0.28)\end{array}$ \\
\hline Policy $\operatorname{rate}_{c, t} \times$ isCOVID $_{c, t}$ & $\begin{array}{l}-0.16^{* * *} \\
(0.02)\end{array}$ & $\begin{array}{l}-0.80^{* * *} \\
(0.10)\end{array}$ & $\begin{array}{c}-0.05 \\
(0.04)\end{array}$ & $\begin{array}{c}-0.16^{* *} \\
(0.08)\end{array}$ & $\begin{array}{c}0.02 \\
(0.04)\end{array}$ & $\begin{array}{c}0.10 \\
(0.12)\end{array}$ & $\begin{array}{c}0.00 \\
(0.02)\end{array}$ & $\begin{array}{l}0.21^{* *} \\
(0.09)\end{array}$ \\
\hline isCOVID $_{c, t} \times$ isDeveloped & & & & & & & $\begin{array}{c}-0.23^{* *} \\
(0.11)\end{array}$ & $\begin{array}{l}1.77^{* * *} \\
(0.48)\end{array}$ \\
\hline New Covid $\operatorname{cases}_{c, t} \times$ isDeveloped & & & & & & & $\begin{array}{c}-0.04 \\
(0.08)\end{array}$ & $\begin{array}{l}-2.97^{* * *} \\
(0.49)\end{array}$ \\
\hline Lockdown stringency ${ }_{c, t} \times$ isDeveloped & & & & & & & $\begin{array}{c}0.12 \\
(0.09)\end{array}$ & $\begin{array}{l}-1.39^{* * *} \\
(0.25)\end{array}$ \\
\hline Fiscal stimulus $_{c, t} \times$ isDeveloped & & & & & & & $\begin{array}{c}-0.03 \\
(0.02)\end{array}$ & $\begin{array}{l}-1.32^{* * *} \\
(0.46)\end{array}$ \\
\hline Policy $\operatorname{rate}_{c, t} \times$ isDeveloped & & & & & & & $\begin{array}{c}-0.64^{* *} \\
(0.26)\end{array}$ & $\begin{array}{l}0.84^{* * *} \\
(0.19)\end{array}$ \\
\hline Policy rate $_{c, t} \times$ isCOVID $_{c, t} \times$ isDeveloped & & & & & & & $\begin{array}{c}-0.14 \\
(0.10)\end{array}$ & $\begin{array}{c}0.03 \\
(0.34)\end{array}$ \\
\hline Num. obs. & 11094 & 10993 & 11032 & 10993 & 11032 & 10993 & 11094 & 10993 \\
\hline $\mathrm{R}^{2}$ (full model) & 0.45 & 0.35 & 0.86 & 0.73 & 0.95 & 0.93 & 0.83 & 0.94 \\
\hline Adj. $\mathrm{R}^{2}$ (full model) & 0.45 & 0.35 & 0.85 & 0.71 & 0.93 & 0.91 & 0.75 & 0.91 \\
\hline$E_{t-1}\{\mathrm{LHS}\}$ & $\checkmark$ & $\checkmark$ & $\checkmark$ & $\checkmark$ & $\checkmark$ & $\checkmark$ & $\checkmark$ & $\checkmark$ \\
\hline country FE & $\checkmark$ & $\checkmark$ & $\checkmark$ & $\checkmark$ & $\checkmark$ & $\checkmark$ & $\checkmark$ & $\checkmark$ \\
\hline week FE & $x$ & $x$ & $\checkmark$ & $\checkmark$ & $\checkmark$ & $\checkmark$ & $\checkmark$ & $\checkmark$ \\
\hline week $\times$ isDeveloped FE & $x$ & $x$ & $\checkmark$ & $\checkmark$ & $\checkmark$ & $\checkmark$ & $\checkmark$ & $\checkmark$ \\
\hline month $\times$ country FE & $x$ & $x$ & $x$ & $x$ & $\checkmark$ & $\checkmark$ & $\checkmark$ & $\checkmark$ \\
\hline
\end{tabular}

Notes: All specifications use robust standard errors, clustered at country and year groups. LHS is total net flows, defined as the sum of equity and bond flows per country. All specifications control for expected flows as discussed in the text. For every fixed effect specification, the first column presents the contemporaneous effects, where the second column presents the cumulative one month effect. Columns 5 and 6 use our preferred fixed effect specification. Columns 7 and 8 condition the results on the country group (DMs and EMs). 
Figure 5: Response of cumulative total flows to domestic COVID pull factors

EMs
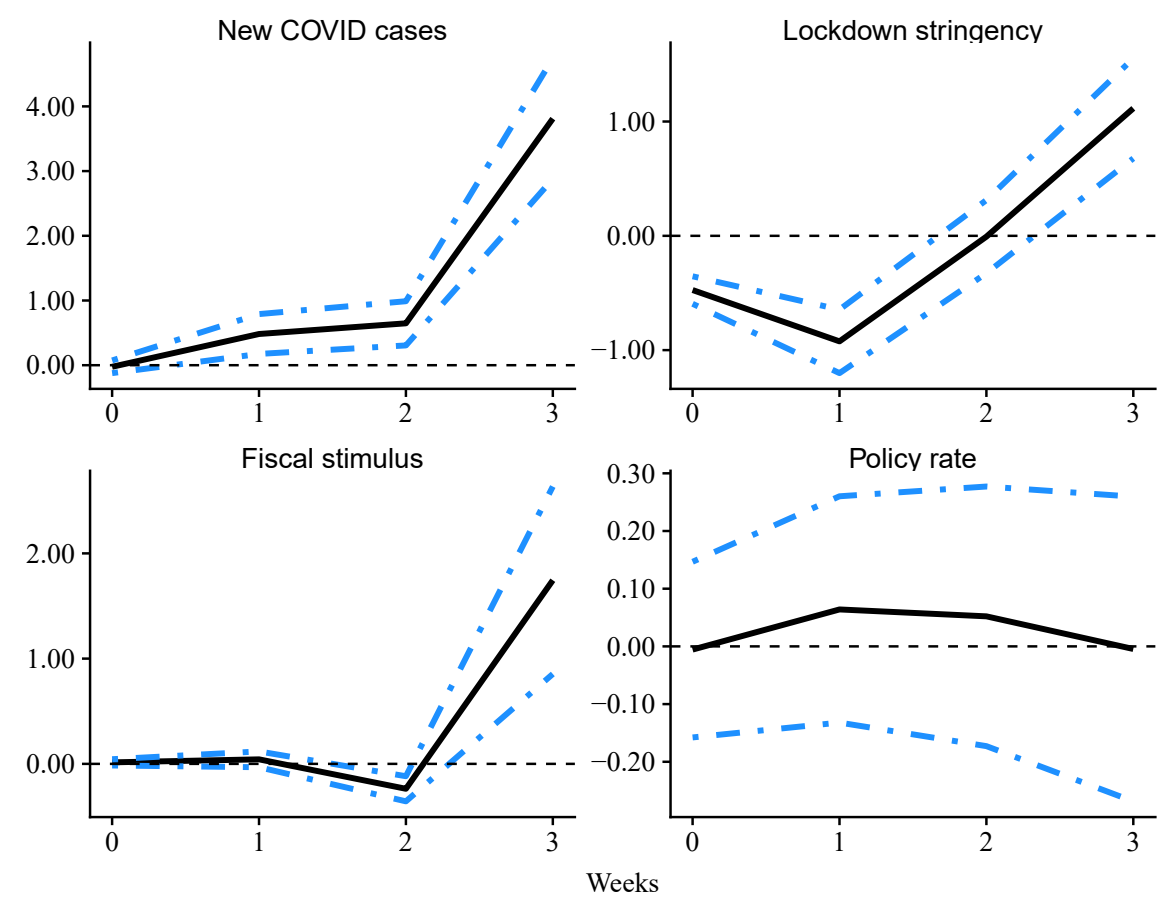

DMs
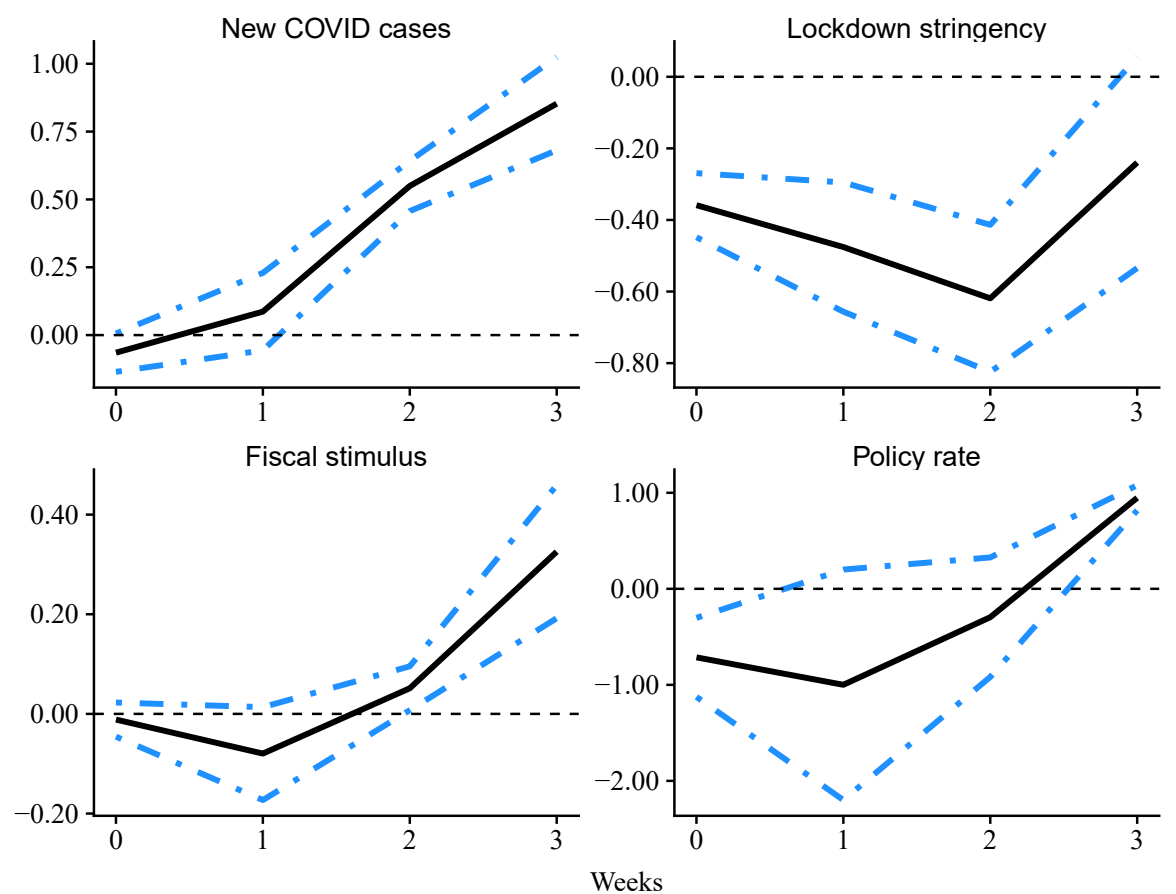

Notes: Estimation follows the specification in column (7) in table 2; it excludes the interaction term between the policy rate and a COVID dummy in order to fit the impact of policy rate in a single chart. To get the DM estimates, we switch the benchmark group in the specification to DMs, and using isEmerging interaction instead of isDeveloped. 
Table 3: The effect of domestic COVID factors on bond and equity flows (foreign domicile)

\begin{tabular}{|c|c|c|c|c|c|c|c|c|}
\hline & \multicolumn{4}{|c|}{ Bond flows } & \multicolumn{4}{|c|}{ Equity flows } \\
\hline & (1) & $(2)$ & $(3)$ & (4) & (5) & (6) & (7) & (8) \\
\hline & $\mathrm{h}=0$ & $\operatorname{cum}(\mathrm{h}=0: 3)$ & $\mathrm{h}=0$ & $\operatorname{cum}(\mathrm{h}=0: 3)$ & $\mathrm{h}=0$ & $\operatorname{cum}(\mathrm{h}=0: 3)$ & $\mathrm{h}=0$ & $\operatorname{cum}(\mathrm{h}=0: 3)$ \\
\hline \multirow[t]{2}{*}{ New COVID $\operatorname{cases}_{c, t}$} & $-0.07^{* * *}$ & $1.36^{* * *}$ & $-0.10^{* *}$ & $4.55^{* * *}$ & 0.02 & $-0.23^{* * *}$ & 0.02 & $-0.49^{* * *}$ \\
\hline & $(0.01)$ & $(0.07)$ & $(0.04)$ & $(0.39)$ & $(0.01)$ & $(0.03)$ & $(0.02)$ & $(0.09)$ \\
\hline \multirow[t]{2}{*}{ Lockdown stringency $_{c, t}$} & $-0.25^{* * *}$ & $0.51^{* * *}$ & $-0.37^{* * *}$ & $1.61^{* * *}$ & $-0.11^{* * *}$ & $-0.19^{* * *}$ & -0.04 & $-0.46^{* * *}$ \\
\hline & $(0.03)$ & $(0.17)$ & $(0.05)$ & $(0.21)$ & $(0.03)$ & $(0.06)$ & $(0.05)$ & $(0.09)$ \\
\hline \multirow{2}{*}{ Fiscal stimulus $_{c, t}$} & -0.01 & $0.21^{* * *}$ & $0.03^{* * *}$ & $0.73^{* * *}$ & $0.03^{* * *}$ & $0.13^{* * *}$ & -0.01 & $0.85^{* * *}$ \\
\hline & $(0.01)$ & $(0.07)$ & $(0.01)$ & $(0.20)$ & $(0.01)$ & $(0.05)$ & $(0.01)$ & $(0.26)$ \\
\hline \multirow{2}{*}{ Policy rate $_{c, t}$} & -0.03 & 0.00 & -0.01 & -0.00 & -0.01 & 0.01 & 0.01 & -0.02 \\
\hline & $(0.03)$ & $(0.09)$ & $(0.04)$ & $(0.11)$ & $(0.05)$ & $(0.09)$ & $(0.05)$ & $(0.13)$ \\
\hline \multirow[t]{2}{*}{ isCOVID $_{c, t}$} & 0.02 & $-0.36^{* *}$ & 0.03 & $-0.85^{* * *}$ & $0.06^{*}$ & $-0.35^{* *}$ & $0.15^{* * *}$ & $-0.63^{* *}$ \\
\hline & $(0.03)$ & $(0.14)$ & $(0.06)$ & $(0.28)$ & $(0.03)$ & $(0.18)$ & $(0.05)$ & $(0.29)$ \\
\hline \multirow[t]{2}{*}{ Policy rate $_{c, t} \times$ isCOVID $_{c, t}$} & $0.02^{*}$ & $0.15^{* * *}$ & $0.03^{* *}$ & $0.23^{* * *}$ & -0.02 & -0.04 & -0.04 & -0.02 \\
\hline & $(0.01)$ & $(0.04)$ & $(0.01)$ & $(0.05)$ & $(0.02)$ & $(0.08)$ & $(0.03)$ & $(0.08)$ \\
\hline \multirow[t]{2}{*}{ isCOVID $_{c, t} \times$ isDeveloped } & & & $-0.18^{* * *}$ & $1.19^{* * *}$ & & & $-0.13^{* * *}$ & $0.54^{*}$ \\
\hline & & & $(0.06)$ & $(0.33)$ & & & $(0.04)$ & $(0.29)$ \\
\hline \multirow{2}{*}{ New COVID cases $_{c, t} \times$ isDeveloped } & & & 0.07 & $-3.47^{* * *}$ & & & -0.02 & $0.24^{* *}$ \\
\hline & & & $(0.06)$ & $(0.42)$ & & & $(0.03)$ & $(0.12)$ \\
\hline \multirow[t]{2}{*}{ Lockdown stringency $_{c, t} \times$ isDeveloped } & & & $0.19^{* * *}$ & $-1.88^{* * *}$ & & & $-0.13^{* *}$ & $0.50^{* * *}$ \\
\hline & & & $(0.06)$ & $(0.25)$ & & & $(0.06)$ & $(0.10)$ \\
\hline \multirow[t]{2}{*}{ Fiscal stimulus $_{c, t} \times$ isDeveloped } & & & $-0.06^{* * *}$ & $-0.47^{* *}$ & & & $0.05^{* * *}$ & $-0.79^{* * *}$ \\
\hline & & & $(0.01)$ & $(0.22)$ & & & $(0.01)$ & $(0.27)$ \\
\hline \multirow[t]{2}{*}{ Policy rate $_{c, t} \times$ isDeveloped } & & & -0.27 & 0.17 & & & $-0.30^{* * *}$ & $0.66^{* * *}$ \\
\hline & & & $(0.24)$ & $(0.27)$ & & & $(0.09)$ & $(0.25)$ \\
\hline \multirow[t]{2}{*}{ Policy rate $_{c, t} \times$ isCOVID $\times$ isDeveloped } & & & $-0.14^{* *}$ & 0.08 & & & 0.03 & -0.06 \\
\hline & & & $(0.06)$ & $(0.13)$ & & & $(0.03)$ & $(0.11)$ \\
\hline Num. obs. & 11094 & 10993 & 11094 & 10993 & 11094 & 10993 & 11094 & 10993 \\
\hline $\mathrm{R}^{2}$ (full model) & 0.90 & 0.94 & 0.90 & 0.94 & 0.71 & 0.89 & 0.71 & 0.89 \\
\hline Adj. $\mathrm{R}^{2}$ (full model) & 0.86 & 0.92 & 0.86 & 0.92 & 0.59 & 0.85 & 0.59 & 0.85 \\
\hline$E_{t-1}\{\mathrm{LHS}\}$ & $\checkmark$ & $\checkmark$ & $\checkmark$ & $\checkmark$ & $\checkmark$ & $\checkmark$ & $\checkmark$ & $\checkmark$ \\
\hline country FE & $\checkmark$ & $\checkmark$ & $\checkmark$ & $\checkmark$ & $\checkmark$ & $\checkmark$ & $\checkmark$ & $\checkmark$ \\
\hline week FE & $\checkmark$ & $\checkmark$ & $\checkmark$ & $\checkmark$ & $\checkmark$ & $\checkmark$ & $\checkmark$ & $\checkmark$ \\
\hline week $\times$ isDeveloped $\mathrm{FE}$ & $\checkmark$ & $\checkmark$ & $\checkmark$ & $\checkmark$ & $\checkmark$ & $\checkmark$ & $\checkmark$ & $\checkmark$ \\
\hline month $\times$ country FE & $\checkmark$ & $\checkmark$ & $\checkmark$ & $\checkmark$ & $\checkmark$ & $\checkmark$ & $\checkmark$ & $\checkmark$ \\
\hline
\end{tabular}

Notes: All specifications use robust standard errors, clustered at country and year groups. LHS is bond and equity net flows. Columns one and two present the contemporaneous and cumulative effects on bond flows, respectively. Columns three and four condition on the country group (DMs and EMs). Similarily, columns five to eight present the effect on equity flows. 
Table 4: The effect of domestic COVID factors on CDS spreads

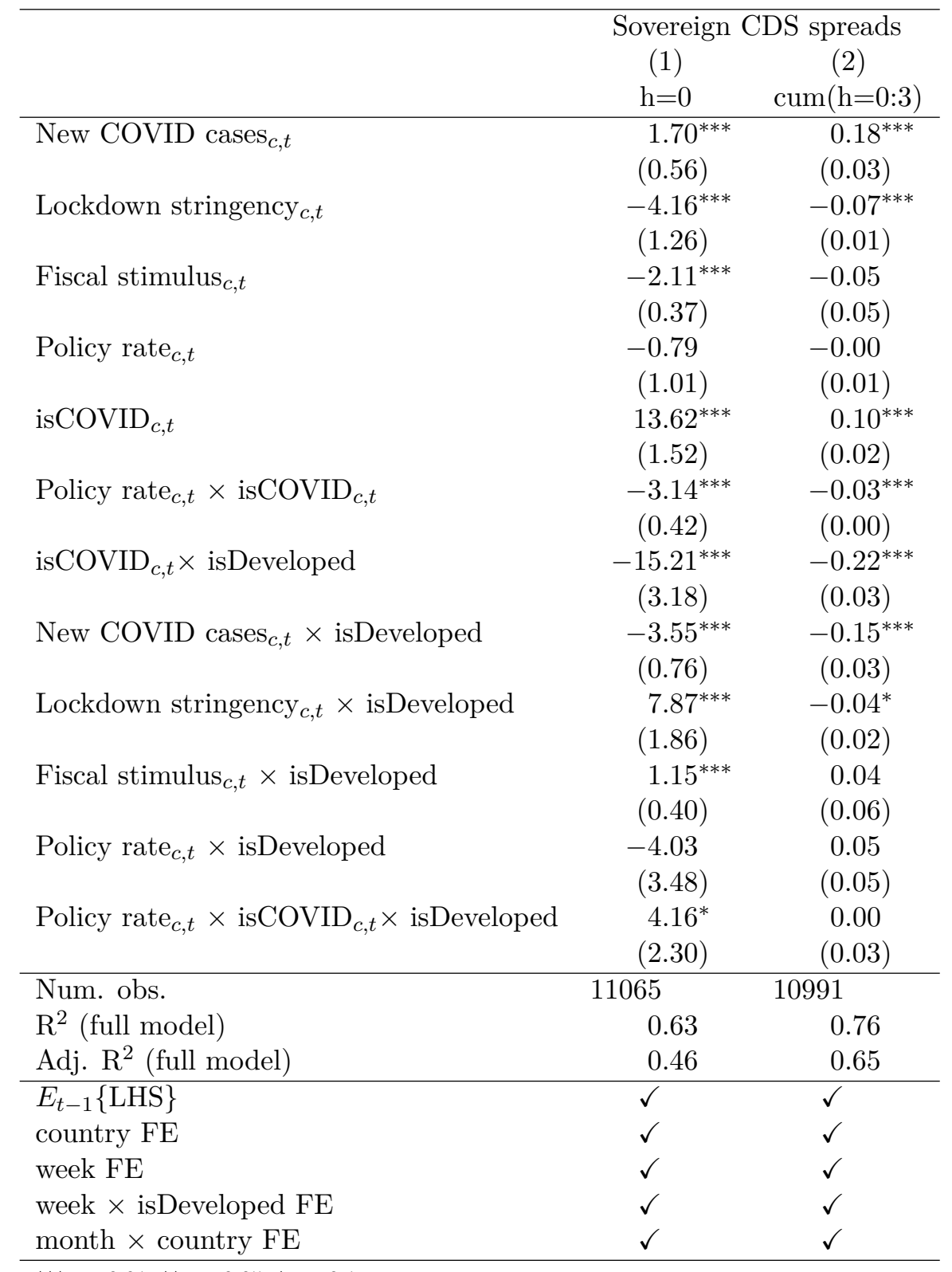

Notes: All specifications use robust standard errors, clustered at country and year groups. LHS is the growth rate of CDS spreads for sovereigns and financial and corporate sectors, respectively. The first two columns of each LHS variable present the average contemporaneous and cumulative effects (i.e. effect on monthly growth rate), respectively, across all countries. The third and forth columns condition the results on country groups (DMs and EMs).

\subsection{Response of domestic-domiciled portfolio flows}

Unlike for foreign investors who tend to be more diversified, domestic investors' balance sheet is more vulnerable to countries' idiosyncratic shocks. This exposure adds an additional dimension to their response to domestic shocks, when compared to that of foreign investors (Caballero and 
Simsek, 2020). Moreover, as Maggiori et al. (2020) point out, domestic investors are more likely to hold assets in local currency, which can amplify the effects of domestic fluctuations. In contrast, foreign investors allocate their funds to foreign-denominated assets, which offer better insulation from local shocks and exchange rate fluctuations. Table 5 reports how the response of investors varied depending on their domicile. Overall, we find evidence that domestic and foreign investors responded differently to the spread of the pandemic and policy measures, resulting in lower domestic flows relative to foreign flows.

While foreign investors eventually increased their fund holdings in response to an increase in the number of new COVID cases, potentially responding to domestic financing needs as discussed above, domestic investors had a far more muted positive response. The impact of lockdown measures on foreign and domestic funds was also heterogeneous. Cumulatively, both foreign- and domesticdomiciled investors increased their allocations. However, only domestic funds experienced a negative initial response, and their cumulative positive response was smaller in magnitude compared to foreign funds. This finding suggests that the negative effects of the economic shutdown may have played a larger role for domestic investors, in line with their greater exposure to domestic shocks.

We find a similar pattern in response to fiscal measures, providing further support to the general idea that domestic-domiciled funds are more sensitive to domestic fluctuations. While foreigndomiciled fund flows increased in response to fiscal stimulus, flows from domestic investors declined over the one-month horizon. Likewise, the positive contemporaneous impact of fiscal stimulus on portfolio flows was weaker for domestic-domiciled flows. Finally, the negative response of portfolio flows to monetary policy was considerably stronger for domestic investors, as reflected in the larger reduction in their allocations in repose to a policy rate cut during the COVID episode. The negative impact of this monetary policy change on the domestic currency could be one explanation why domestic funds experienced negative pressures as policy eased.

\subsection{Policy measures and the global shock}

Thus far, the analysis has focused on the average effects of domestic COVID cases and policy shocks, and abstracted from the interaction of policies with global drivers of flows during the COVID episode. However, one of the key channels through which these measures could have mattered for portfolio flows is through mitigating or exacerbating the impact of the global shock. In this section, we examine this interaction between the global shock and the enacted policy measures.

We start by estimating the effects of the interaction between the VIX, as a continuous measure of global investment sentiment, and the lagged values of the policy measures. Given the fluid and dynamic nature of the COVID crisis, we believe that a market-based measure is more successful in reflecting the evolving intensity of the global shock in comparison to an agnostic time dummy. Observed fluctuations in the VIX align with those of global outflows, capturing the changes in markets as the virus spread. In this respect, our analysis (table 6, columns 1 and 2) shows that an increase in the VIX was associated with a negative and significant response in net portfolio flows. We relax the week fixed effects and country $\times$ month fixed effects to estimate the effect of the VIX and to ensure we have sufficient variation in the level of VIX over the duration of the COVID 
Table 5: The effect of domestic COVID factors on total flows by domicile

\begin{tabular}{|c|c|c|}
\hline & $\begin{array}{c}(1) \\
\mathrm{h}=0\end{array}$ & $\begin{array}{c}(2) \\
\operatorname{cum}(\mathrm{h}=0: 3)\end{array}$ \\
\hline New COVID cases $_{c, t}$ & $\begin{array}{c}-0.17^{* * *} \\
(0.04)\end{array}$ & $\begin{array}{l}0.93^{\text {*** }} \\
(0.16)\end{array}$ \\
\hline Lockdown stringency $_{c, t}$ & $\begin{array}{r}-0.03 \\
(0.08)\end{array}$ & $\begin{array}{l}2.20^{* * *} \\
(0.20)\end{array}$ \\
\hline Fiscal stimulus $_{c, t}$ & $\begin{array}{l}0.12^{\text {*** }} \\
(0.03)\end{array}$ & $\begin{array}{l}0.17^{* *} \\
(0.08)\end{array}$ \\
\hline 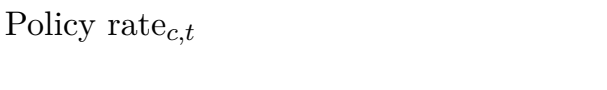 & $\begin{array}{r}-0.13 \\
(0.10)\end{array}$ & $\begin{array}{r}-0.03 \\
(0.18)\end{array}$ \\
\hline isCOVID $_{c, t}$ & $\begin{array}{c}-0.33^{* * *} \\
(0.05)\end{array}$ & $\begin{array}{c}-1.67^{* * *} \\
(0.26)\end{array}$ \\
\hline 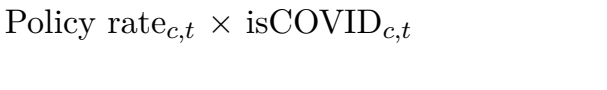 & $\begin{array}{r}-0.01 \\
(0.02)\end{array}$ & $\begin{array}{l}0.15^{* *} \\
(0.07)\end{array}$ \\
\hline isCOVID $_{c, t} \times$ isDomestic & $\begin{array}{l}0.96^{* * *} \\
(0.05)\end{array}$ & $\begin{array}{l}4.32^{* * *} \\
(0.38)\end{array}$ \\
\hline 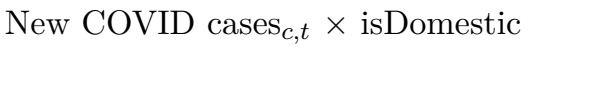 & $\begin{array}{r}-0.03 \\
(0.08)\end{array}$ & $\begin{array}{c}-0.85^{* * *} \\
(0.21)\end{array}$ \\
\hline Lockdown stringency $_{c, t} \times$ isDomestic & $\begin{array}{c}-0.17^{* * *} \\
(0.06)\end{array}$ & $\begin{array}{c}-0.61^{* *} \\
(0.24)\end{array}$ \\
\hline Fiscal stimulus $_{c, t} \times$ isDomestic & $\begin{array}{c}-0.06^{* * *} \\
(0.02)\end{array}$ & $\begin{array}{c}-0.20^{* * *} \\
(0.07)\end{array}$ \\
\hline 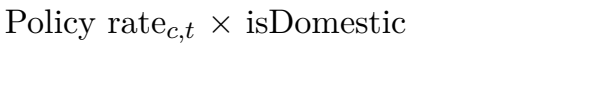 & $\begin{array}{r}-0.02 \\
(0.02)\end{array}$ & $\begin{array}{r}-0.10 \\
(0.11)\end{array}$ \\
\hline Policy rate $_{c, t} \times$ isCOVID $\times$ isDomestic & $\begin{array}{l}0.26^{* * *} \\
(0.04)\end{array}$ & $\begin{array}{l}0.91^{* * *} \\
(0.11)\end{array}$ \\
\hline Num. obs. & 17884 & 17447 \\
\hline $\mathrm{R}^{2}$ (full model) & 0.56 & 0.71 \\
\hline Adj. $\mathrm{R}^{2}$ (full model) & 0.46 & 0.64 \\
\hline$E_{t-1}\{\mathrm{LHS}\}$ & $\checkmark$ & $\checkmark$ \\
\hline country FE & $\checkmark$ & $\checkmark$ \\
\hline week FE & $\checkmark$ & $\checkmark$ \\
\hline week $\times$ isDeveloped FE & $\checkmark$ & $\checkmark$ \\
\hline month $\times$ country FE & $\checkmark$ & $\checkmark$ \\
\hline
\end{tabular}

Notes: All specifications use robust standard errors, clustered at country and year groups. LHS is total net flows, defined as the sum of equity and bond flows per country. Columns one and two present the contemporaneous and cumulative effects, respectively, conditioning on the domicile group (Foreign and Domestic). 
episode.

Table 6 (columns 3 and 4) reports the results for the interaction between the global shock and policy measures. Our findings suggest that lockdown measures mitigated the adverse impact of the global shock on portfolio flows over the one-month horizon while they didn't change the sensitivity to the global shock upon impact. Between any two economies that differed in the intensity of their lockdown measures by one standard deviation, a one percent increase in the global VIX index was associated with an increase in net flows by 6.77 standard deviations in the country with the more stringent lockdown.

Our results also show that discretionary fiscal spending played a significant role in mitigating the impact of the VIX contemporaneously and exacerbating it over the horizon of one month. Between any two countries that differed in the amount of their fiscal spending by one percent of GDP, a one percent increase in the VIX index was associated with a 1.00 standard deviation increase in net flows in the country with the higher spending level contemporaneously. The cumulative effect was negative, however, suggesting that net flows were 0.95 standard deviations lower in the country with the higher fiscal spending. This less expected finding could be understood in light of the negative effect of the fiscal stimulus on public debt sustainability, which appears to have adversely contributed to the global wave of portfolio reallocation triggered by the pandemic. An alternative explanation may suggest a potential dependency between the size of the fiscal stimulus and countries exposure to external and global fluctuations, whereby countries that expected a larger downturn had to spend more early on. However, the country fixed effects in our specification control for such channels.

In contrast to fiscal spending, we find that expansionary monetary policy actions were successful in attenuating the negative impact of the global shock both upon impact and over the one-month horizon. Between any two countries that differed with respect to their interest rate differential to the U.S. by a hundred basis points, a hundred percent increase in the VIX index was contemporaneously associated with a higher level of net flows by a 0.27 standard deviations in the country with the lower rate. The estimated cumulative effect was 0.25 standard deviations higher for the country with the lower interest rate.

\subsection{Pre-COVID macroeconomic conditions and policy space}

Finally, we turn to the role of macroeconomic conditions for portfolio flows. Our analysis interacts a country-specific COVID dummy — which takes the value one for each country-time observation when the number of COVID cases is positive and zero otherwise - with pre-COVID indicators capturing the economy's macroeconomic environments and policy space. We particularly focus on the fiscal and external positions of the economy. To ensure that we capture the long-term value of fundamentals, rather than short-term fluctuations, we take the average value over 2014-2019. Our findings in table 7 suggest that pre-COVID public debt, sovereign risk, reserves, and trade openness played a significant role in determining the response of portfolio flows to the pandemic.

We find that countries with higher sovereign default risk, i.e. higher CDS spread, suffered a stronger fall in portfolio flows. Our estimates indicate that for two countries that differ in their CDS 
Table 6: Policy measures and the global shock (total foreign domicile flows)

\begin{tabular}{|c|c|c|c|c|}
\hline & $\begin{array}{c}(1) \\
h=0\end{array}$ & $\begin{array}{c}(2) \\
\operatorname{cum}(\mathrm{h}=0: 3)\end{array}$ & $\begin{array}{c}(3) \\
h=0\end{array}$ & $\begin{array}{c}(4) \\
\operatorname{cum}(\mathrm{h}=0: 3)\end{array}$ \\
\hline New COVID $\operatorname{cases}_{c, t-1}$ & $\begin{array}{c}0.13 \\
(0.09)\end{array}$ & $\begin{array}{c}0.93 \\
(0.60)\end{array}$ & $\begin{array}{l}0.19^{* * *} \\
(0.07)\end{array}$ & $\begin{array}{c}0.74^{* *} \\
(0.32)\end{array}$ \\
\hline Lockdown stringency ${ }_{c, t-1}$ & $\begin{array}{c}-0.07 \\
(0.25)\end{array}$ & $\begin{array}{c}0.87^{*} \\
(0.50)\end{array}$ & $\begin{array}{c}0.02 \\
(0.83)\end{array}$ & $\begin{array}{c}-20.40^{* * *} \\
(4.55)\end{array}$ \\
\hline Fiscal stimulus $_{c, t-1}$ & $\begin{array}{l}0.20^{* * *} \\
(0.04)\end{array}$ & $\begin{array}{c}-0.18 \\
(0.13)\end{array}$ & $\begin{array}{c}-3.44^{* * *} \\
(0.40)\end{array}$ & $\begin{array}{r}3.50^{*} \\
(1.88)\end{array}$ \\
\hline Policy rate $_{c, t-1}$ & $\begin{array}{c}-0.84 \\
(0.77)\end{array}$ & $\begin{array}{c}-0.60^{* *} \\
(0.25)\end{array}$ & $\begin{array}{c}0.03 \\
(0.49)\end{array}$ & $\begin{array}{c}0.12 \\
(0.29)\end{array}$ \\
\hline $\log (\mathrm{VIX})_{t}$ & $\begin{array}{c}-3.26^{* * *} \\
(0.68)\end{array}$ & $\begin{array}{c}-5.12^{* *} \\
(2.14)\end{array}$ & $\begin{array}{c}-1.72^{* * *} \\
(0.25)\end{array}$ & $\begin{array}{c}-2.30^{* * *} \\
(0.63)\end{array}$ \\
\hline $\log (\mathrm{VIX})_{t} \times$ isDeveloped & $\begin{array}{l}1.75^{* * *} \\
(0.45)\end{array}$ & $\begin{array}{l}2.32^{* *} \\
(1.02)\end{array}$ & & \\
\hline $\operatorname{isCOVID~}_{c, t}$ & & & $\begin{array}{l}6.90^{* * *} \\
(1.00)\end{array}$ & $\begin{array}{l}15.96^{* * *} \\
(2.54)\end{array}$ \\
\hline $\operatorname{isCOVID~}_{c, t} \times \log (\mathrm{VIX})_{t}$ & & & $\begin{array}{c}-2.26^{* * *} \\
(0.33)\end{array}$ & $\begin{array}{c}-7.06^{* * *} \\
(0.75)\end{array}$ \\
\hline Lockdown stringency $_{c, t-1} \times \log (\mathrm{VIX})_{t}$ & & & $\begin{array}{c}0.13 \\
(0.24)\end{array}$ & $\begin{array}{l}6.77^{* * *} \\
(1.12)\end{array}$ \\
\hline Fiscal stimulus $_{c, t-1} \times \log (\mathrm{VIX})_{t}$ & & & $\begin{array}{l}1.00^{* * *} \\
(0.12)\end{array}$ & $\begin{array}{c}-0.95^{* *} \\
(0.49)\end{array}$ \\
\hline 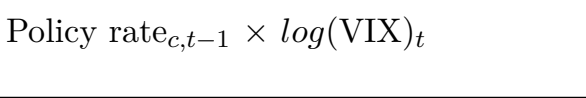 & & & $\begin{array}{c}-0.27^{* * *} \\
(0.07)\end{array}$ & $\begin{array}{c}-0.25^{* *} \\
(0.11)\end{array}$ \\
\hline Num. obs. & 11031 & 10994 & 11031 & 10994 \\
\hline $\mathrm{R}^{2}$ (full model) & 0.75 & 0.23 & 0.75 & 0.31 \\
\hline Adj. $\mathrm{R}^{2}$ (full model) & 0.75 & 0.23 & 0.75 & 0.31 \\
\hline$E_{t-1}\{\mathrm{LHS}\}$ & $\checkmark$ & $\checkmark$ & $\checkmark$ & $\checkmark$ \\
\hline country FE & $\checkmark$ & $\checkmark$ & $\checkmark$ & $\checkmark$ \\
\hline
\end{tabular}

Notes: All specifications use robust standard errors, clustered at country and year groups. LHS is total net flows, defined as the sum of equity and bond flows per country. 
spread by one percent, net flows were lower by 0.15 and 0.47 standard deviations upon impact and cumulatively, respectively, in the country with the higher default risk. Importantly, the results show that government spending is less relevant for capital market dynamics once default risk is accounted for; conditioning on CDS spreads, government deficit does not appear to have significantly mattered for the magnitude of portfolio flows.

Our results also show that countries with a higher public debt-to-GDP ratio experienced larger net portfolio flows during the pandemic. For two countries that differ in their debt-to-GDP ratio by one percentage point, net flows were higher by 0.02 standard deviations cumulatively in the country with the higher debt level. While the economic significance of the estimated coefficients is rather limited, the result suggests that, in our sample, a higher average value of debt to GDP is more likely to be associated with a higher level of debt tolerance not fiscal risk, particularly as our specification controls for sovereign default risk (CDS spread). Higher debt tolerance is typically a result of improved structural institutions as well as future growth potential, which become even more attractive for foreign funds during a high uncertainty regime.

We also find that the decline in flows was less severe in economies that enjoyed larger preCOVID trade openness, reflecting investors' perception that more open economies could cushion the shock to domestic demand through their larger external sector. For two countries that differed in their trade-to-GDP ratio by one percentage point, the more open economy saw larger net portfolio flows by 0.01 standard deviations contemporaneously and by 0.03 standard deviations cumulatively. While the size of trade was an important factor, the current account was not. Nonetheless, this finding is conditional on the size of reserves to GDP ratio which had a significant mitigating effect of 0.06 standard deviations upon impact.

\subsection{Historical contribution of domestic COVID factors and global shocks}

Thus far, the analysis has focused on quantifying the elasticity of portfolio flows to changes in COVID cases and policy measures. While these elasticity estimates are informative about the expected effect of a particular shock on portfolio flows, they may not provide insights into its actual contribution to the observed historical dynamics of portfolio flows. In this section, we compute the contribution of the COVID-related factors to total flows between March $4^{\text {th }}$ and May $13^{\text {th }}, 2020$. The former date corresponds to the first week of the COVID episode, while the latter is the end of our sample. We present only the contribution of contemporaneous changes in the domestic COVID related factors and the global factor. We take this exercise to be more suggestive than conclusive since a more complete picture requires accounting for the effects of all lagged shocks, which is constrained by the short horizon of the sample period. The second important caveat to keep in mind is that the historical decomposition analysis relies on point estimates, which abstract from estimation uncertainty.

We start by estimating the elasticities of the domestic and global factors,

$$
\begin{aligned}
\text { Flows }_{c, t}= & E_{t-1}\left\{\text { Flows }_{c, t}\right\}+\beta_{1} \text { New COVID Cases } \\
c, t & +\beta_{2} \operatorname{Lockdown}_{c, t}+ \\
& \beta_{3} \text { Fiscal Stimulus } c, t+\beta_{4} \text { Policy Rate }_{c, t}+\beta_{5} \log (V I X)_{t}+\eta_{c}
\end{aligned}
$$


Table 7: Macroeconomic fundamentals and portfolio flows (total foreign domicile flows)

\begin{tabular}{|c|c|c|}
\hline & $\begin{array}{c}(1) \\
h=0\end{array}$ & $\begin{array}{c}(2) \\
\operatorname{cum}(\mathrm{h}=0: 3)\end{array}$ \\
\hline New Covid cases $_{c, t}$ & $\begin{array}{c}-0.19^{* * *} \\
(0.05)\end{array}$ & $\begin{array}{c}0.18 \\
(0.20)\end{array}$ \\
\hline Lockdown stringency $_{c, t}$ & $\begin{array}{r}-0.27 \\
(0.17)\end{array}$ & $\begin{array}{c}0.52 \\
(0.45)\end{array}$ \\
\hline Fiscal stimulus $_{c, t}$ & $\begin{array}{r}-0.03 \\
(0.02)\end{array}$ & $\begin{array}{c}0.02 \\
(0.05)\end{array}$ \\
\hline Policy rate $_{c, t}$ & $\begin{array}{c}0.02 \\
(0.07)\end{array}$ & $\begin{array}{r}-0.05 \\
(0.13)\end{array}$ \\
\hline isCOVID $_{c, t}$ & $\begin{array}{c}-2.67^{* * *} \\
(0.98)\end{array}$ & $\begin{array}{c}-5.36^{* *} \\
(2.49)\end{array}$ \\
\hline Debt to $\mathrm{GDP}$ ratio $_{c} \times$ isCOVID $_{c, t}$ & $\begin{array}{c}0.00^{*} \\
(0.00)\end{array}$ & $\begin{array}{r}0.01^{*} \\
(0.00)\end{array}$ \\
\hline Fiscal balance to $\mathrm{GDP}_{\text {ratio }_{c}} \times$ isCOVID $_{c, t}$ & $\begin{array}{r}-0.02 \\
(0.04)\end{array}$ & $\begin{array}{r}-0.04 \\
(0.06)\end{array}$ \\
\hline $\log (\mathrm{CDS} \text { spread })_{c} \times$ isCOVID $_{c, t}$ & $\begin{array}{r}-0.15^{*} \\
(0.08)\end{array}$ & $\begin{array}{c}-0.47^{* *} \\
(0.21)\end{array}$ \\
\hline Reserves to GDP ratio $_{c} \times$ isCOVID $_{c, t}$ & $\begin{array}{r}0.06^{*} \\
(0.03)\end{array}$ & $\begin{array}{c}0.09 \\
(0.06)\end{array}$ \\
\hline Current account to GDP ratio $_{c} \times$ isCOVID $_{c, t}$ & $\begin{array}{r}-0.01 \\
(0.02)\end{array}$ & $\begin{array}{r}-0.01 \\
(0.06)\end{array}$ \\
\hline Trade to GDP ratio $_{c} \times$ isCOVID $_{c, t}$ & $\begin{array}{l}0.01^{* * *} \\
(0.00)\end{array}$ & $\begin{array}{l}0.03^{\text {*** }} \\
(0.01)\end{array}$ \\
\hline Num. obs. & 10127 & 10090 \\
\hline $\mathrm{R}^{2}$ (full model) & 0.93 & 0.83 \\
\hline Adj. $\mathrm{R}^{2}$ (full model) & 0.92 & 0.81 \\
\hline$E_{t-1}\{\mathrm{LHS}\}$ & $\checkmark$ & $\checkmark$ \\
\hline country FE & $\checkmark$ & $\checkmark$ \\
\hline week FE & $\checkmark$ & $\checkmark$ \\
\hline week $\times$ isDeveloped $\mathrm{FE}$ & $\checkmark$ & $\checkmark$ \\
\hline month $\times$ country FE & $\checkmark$ & $\checkmark$ \\
\hline
\end{tabular}

Notes: Macroeconomic indicators are calculated as the pre-COVID mean of their respective annual time series for every country. All specifications use robust standard errors, clustered at country and year groups. LHS is total net flows, defined as the sum of equity and bond flows per country. All specifications control for expected flows as discussed in the text. 
In comparison to our baseline specification in equation (1), we relax the week fixed effects and the country $\times$ month fixed effects to estimate the impact of the variations in the global factor, as proxied by VIX, and to capture the historical variation in the domestic factors to a more complete extent. However, we keep the country fixed effects to maintain a degree of control against omitted variables concerns.

In general, computing the contribution of individual independent variables to movements in the dependent variable is not a straightforward exercise. The reason is that the estimated elasticities do not reflect the effects of all movements in the independent variable, but only movements that are orthogonal to all other right-hand-side variables. To tackle this concern, we compute the contribution of a factor $F$ (e.g. New COVID cases, VIX, etc) over two steps. The first step extracts the part of the factor's variations that is independent of other covariates in equation (2). We recover this independent component by regressing the respective factor on the remaining righthand-side variables, including the country fixed effects. The residual of these regression reflects the exogenous variations in $F$, which we refer to as a shock:

$$
\begin{gathered}
\operatorname{shock}_{c, t}^{F_{\text {domestic }}}=F_{c, t}-E\left\{F_{c, t} \mid \text { other COVID factors }+\log (V I X)_{t}+\text { controls }+ \text { fixed effects }\right\} \\
\operatorname{shock}_{t}^{V I X}=\log (V I X)_{t}-E\left\{\log (V I X)_{t} \mid \text { COVID factors }+ \text { controls }+ \text { fixed effects }\right\}
\end{gathered}
$$

In the second step, at each point in time, we account for historical contemporaneous contributions by multiplying the residual component by the coefficients estimated using the previous local projection estimation step: ${ }^{16}$

$$
\text { contribution }_{c, t}^{\text {shock }}{ }^{F}=\beta \times \operatorname{shocks}_{c, t}^{F}
$$

Figure 6 reports the results for the computed contribution shock $^{F}$ for emerging markets. Since the historical contribution of the different factors differ across the distribution of countries, we plot both the median value as well as the first and third quartiles (i.e. $25^{\text {th }}$ and $75^{\text {th }}$ percentile) for the estimated contribution of each of the five factors at each point in time.

The results indicate that global factors played the larger role in explaining portfolio flows movements during the COVID episode. Their effect was negative and orders of magnitude larger in comparison to the COVID-related domestic factors, especially during the early and most uncertain phase of the pandemic. This large difference in magnitude between global and domestic COVID factors also suggests that other county-specific policy and institutional factors were responsible for why the net historical effect on portfolio flows in EMs was not as negative as the contribution of global shocks would suggest.

Interestingly, the contemporaneous contribution of domestic COVID infection shocks does not appear to have been a dominant factor in explaining the displacement we observed in portfolio flows during the COVID episode, conditioning on the global component of the crisis and the policy

\footnotetext{
${ }^{16}$ While the two step approach allows us to evaluate the contribution of the exogenous variations in each factor, it introduces additional source of estimation uncertainty due to the use of estimated regressors.
} 
measures taken by governments. With a negative contemporaneous elasticity, the contribution of COVID shocks was positive in the early part of the sample as countries that experienced a slower virus spread (i.e. negative COVID surprises) maintained higher flows. In the second half of the sample period, the number of cases grew exponentially and the majority of countries experienced positive COVID surprises that prompted lower portfolio flows.

Within the set of domestic policies we explore, the results indicate that lockdown policies had a more pronounced effect on portfolio adjustment decisions; a more stringent lockdown had a notably positive effect during the height of the capital outflows experienced in EMs. However, the contemporaneous contribution of later changes in lockdown policies becomes negative during the second half of the sample period, reflecting the effects of the lockdown loosening shocks that followed. It is important to recall here that our analysis captures only contemporaneous contributions, which abstracts from the persistent positive contribution of lagged positive lockdown stringency shocks.

The contribution of independent monetary policy actions was closely similar and less dispersed across all EMs with the larger effect taking place in early April. As expected, its contribution was quite negative prompting flows to search for yield when most central banks enacted aggressive rate cuts to combat the fall in economic activity. With regards to fiscal policy actions, we find that their contribution was positive for the majority of countries; however, its distribution was quite skewed to the right with a considerably smaller magnitude for the lower two quartiles, reflecting the small elasticity we estimate for the contemporaneous effects of fiscal policy actions on portfolio flows.

Figure 6: Historical contributions to cumulative total flows in EMs
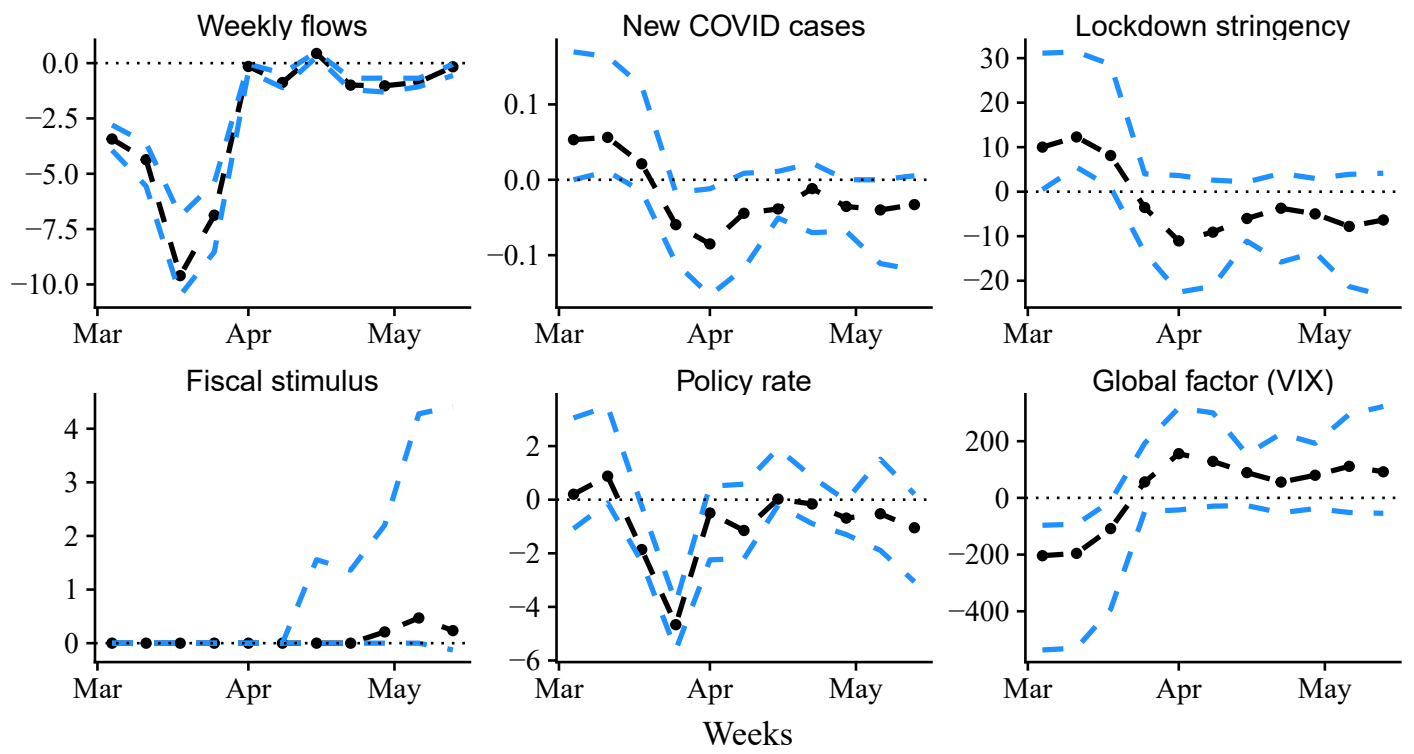

Notes: Estimates of the contemporaneous historical contribution of COVID-related factors and global factor to total flows between March $4^{\text {th }}$ and May $13^{\text {th }}, 2020$. Weekly flows are total flows scaled by total allocations, and normalized by its pre-COVID standard deviation. The black middle line is the median value of factor contribution across the countries distribution, while the two blue lines are the first and third quartiles. 


\section{Conclusion}

The COVID-19 pandemic triggered a drastic reaction of international capital markets. Despite the global nature of the pandemic, there was a large degree of heterogeneity in portfolio flows across countries and asset classes, as well as in governments' policy responses around the world. Some emphasized a trade-off between lives and livelihood while others argued that a well functioning economy can only be sustained when public health is prioritized.

This paper, to the best of our knowledge, provides the first empirical assessment of how the number of infections, the stringency of the lockdown, and fiscal and monetary policy stimulus affected international capital markets during the global health emergency. Our findings indicate that capital market dynamics were not exclusively driven by global push factors. Instead, the severity of the pandemic at the domestic level and governments' policy responses played a role in explaining heterogeneity in portfolio flows and market-implied sovereign risk, particularly in EMs.

One of our key messages is that the pandemic and governments' policy response impacted both the supply and demand curves of capital markets. We find that higher domestic COVID cases led to a cumulative increase in flows, particularly in EMs, responding to widening financing needs. While this flow of funds may have helped countries smooth the effect of the global shocks at the height of the pandemic, it also implies that a large set of emerging and developed market economies might be left to struggle with a larger debt burden in the aftermath of the crisis.

Another element that we highlight in the analysis is that lockdown and fiscal policy measures were successful in stimulating portfolio investment, whereby the response was stronger in EMs. Despite potentially adverse effects of these measures on economic activity and deficit levels, the supply of funds increased in response to stricter containment and fiscal stimulus. Monetary policy cuts were associated with lower flows, particularly in DMs, in line with the pattern we would expect when investors search for yield.

The findings in this paper are particularly relevant for EMs, which tend to be subject to larger policy constraints and fickle capital flows. In the context of the lives vs. livelihood debate, our results imply that markets viewed this potential trade-off as a false dilemma, rewarding countries for enacting a more stringent lockdown. Hence, going forward, public health should remain a priority. In addition, the positive and sizeable effect of fiscal stimulus on portfolio flows points at the importance of countercyclical fiscal policy, particularly as accommodating monetary policy had an adverse effect on portfolio flows. This finding suggests that building fiscal policy buffers in good times and maintaining access to financing during bad times can help EMs in shielding themselves from undesired volatility in capital flows. 


\section{References}

Alfaro, Laura et al. (2020). Aggregate and Firm-Level Stock Returns During Pandemics, in Real Time. Covid Economics: Vetted and Real-Time Papers, CEPR.

Avdjiev, Stefan et al. (2020). "The shifting drivers of global liquidity". Journal of International Economics 125, p. 103324.

Berk, Jonathan B and Richard C Green (2004). "Mutual fund flows and performance in rational markets". Journal of political economy 112.6, pp. 1269-1295.

Broner, Fernando et al. (2013). "Gross capital flows: Dynamics and crises". Journal of Monetary Economics 60.1, pp. $113-133$.

Caballero, Ricardo J and Alp Simsek (2020). "A Model of Fickle Capital Flows and Retrenchment". Journal of Political Economy 128.6, pp. 2288-2328.

Çakmakli, Cem et al. (2020). COVID-19 and Emerging Markets: An Epidemiological Model with International Production Networks and Capital Flows. IMF Working Paper 20/133.

Chari, Anusha, Karlye Dilts Stedman, and Christian T. Lundblad (2020). Capital Flows in Risky Times: Risk-On/Risk-Off and Emerging Market Tail Risk. NBER Working Paper 27927.

Davis, Scott D., Giorgio Valente, and Eric van Wincoop (2019). Global Capital Flows Cycle: Impact on Gross and Net Flows. NBER Working Paper 25721.

Esteves, Rui and Nathan Sussman (2020). The Corona Spreads. Graduate Institute of International and Development Studies.

Forbes, Kristin and Francis Warnock (2011). "Capital Flow Waves: Surges, Stops, Flight and Retrenchment". Journal of International Economics 88.2, pp. 235-251.

Fratzscher, Marcel (2012). "Capital flows, push versus pull factors and the global financial crisis". Journal of International Economics 88.2, pp. 341-356.

Fratzscher, Marcel, Marco Lo Duca, and Roland Straub (2018). "On the international spillovers of US quantitative easing". The Economic Journal 128.608, pp. 330-377.

Gilchrist, Simon and Egon Zakrajšek (2012). "Credit spreads and business cycle fluctuations". American Economic Review 102.4, pp. 1692-1720.

Hale, Thomas et al. (2020). Oxford COVID-19 Government Response Tracker. Blavatnik School of Government.

Jordà, Òscar (2005). "Estimation and inference of impulse responses by local projections". American Economic Review 95.1, pp. 161-182. 
Jotikasthira, Chotibhak, Christian Lundblad, and Tarun Ramadorai (2012). "Asset Fire Sales and Purchases and the International Transmission of Funding Shocks". The Journal of Finance 67.6, pp. 2015-2050.

Kalemli-Özcan, Şebnem (2019). U.S. Monetary Policy and International Risk Spillovers. Prepared for the Jackson Hole Economic Policy Symposium, Federal Reserve Bank of Cansas City.

Kilian, Lutz and Helmut Lütkepohl (2017). Structural vector autoregressive analysis. Cambridge University Press.

Koepke, Robin and Simon Paetzold (2020). Capital Flow Data-A Guide For Empirical Analysis and Real-Time Tracking. IMF Working Paper 20/171.

Maggiori, Matteo, Brent Neiman, and Jesse Schreger (2020). "International Currencies and Capital Allocation". Journal of Political Economy 128.6, pp. 2019-2066.

Miao, Yanlian and Malika Pant (2012). Coincident Indicators of Capital Flows. IMF Working Paper $12 / 55$.

Milesi-Ferretti, Gian-Maria et al. (2011). "The great retrenchment: international capital flows during the global financial crisis". Economic Policy 26.66, pp. 285-342.

Nakamura, Emi and Jón Steinsson (2018). "High-frequency identification of monetary non-neutrality: the information effect". The Quarterly Journal of Economics 133.3, pp. 1283-1330.

Nickell, Stephen (1981). "Biases in dynamic models with fixed effects". Econometrica: Journal of the Econometric Society, pp. 1417-1426.

Rey, Hélène (2015). Dilemma not trilemma: the global financial cycle and monetary policy independence. National Bureau of Economic Research.

Sarno, Lucio, Ilias Tsiakas, and Barbara Ulloa (2016). "What drives international portfolio flows?" Journal of International Money and Finance 60, pp. 53-72. 


\section{Appendix to Capital Markets, COVID-19, and Policy Measures}

\section{A Data}

Table A.1: Country classification

\begin{tabular}{llll}
\hline \multicolumn{2}{l}{ Developed markets } & & \\
Australia & Austria & Belgium & Canada \\
Denmark & Finland & France & Germany \\
Hong Kong SAR & Ireland & Israel & Italy \\
Japan & Netherlands & New Zealand & Norway \\
Portugal & Spain & Sweden & Switzerland \\
United Kingdom & & & \\
\hline Emerging markets & & & \\
Brazil & China & Czech Republic & Greece \\
Indonesia & Malaysia & Mexico & Pakistan \\
Peru & Philippines & Poland & Qatar \\
Saudi Arabia & South Africa & Thailand & Turkey \\
\hline
\end{tabular}

Notes: Countries are categorized according to the 2020 MSCI developed and emerging market classification. 


\section{B Additional figures}

Figure B.1: Cumulative equity and bond flows (percent of allocation)
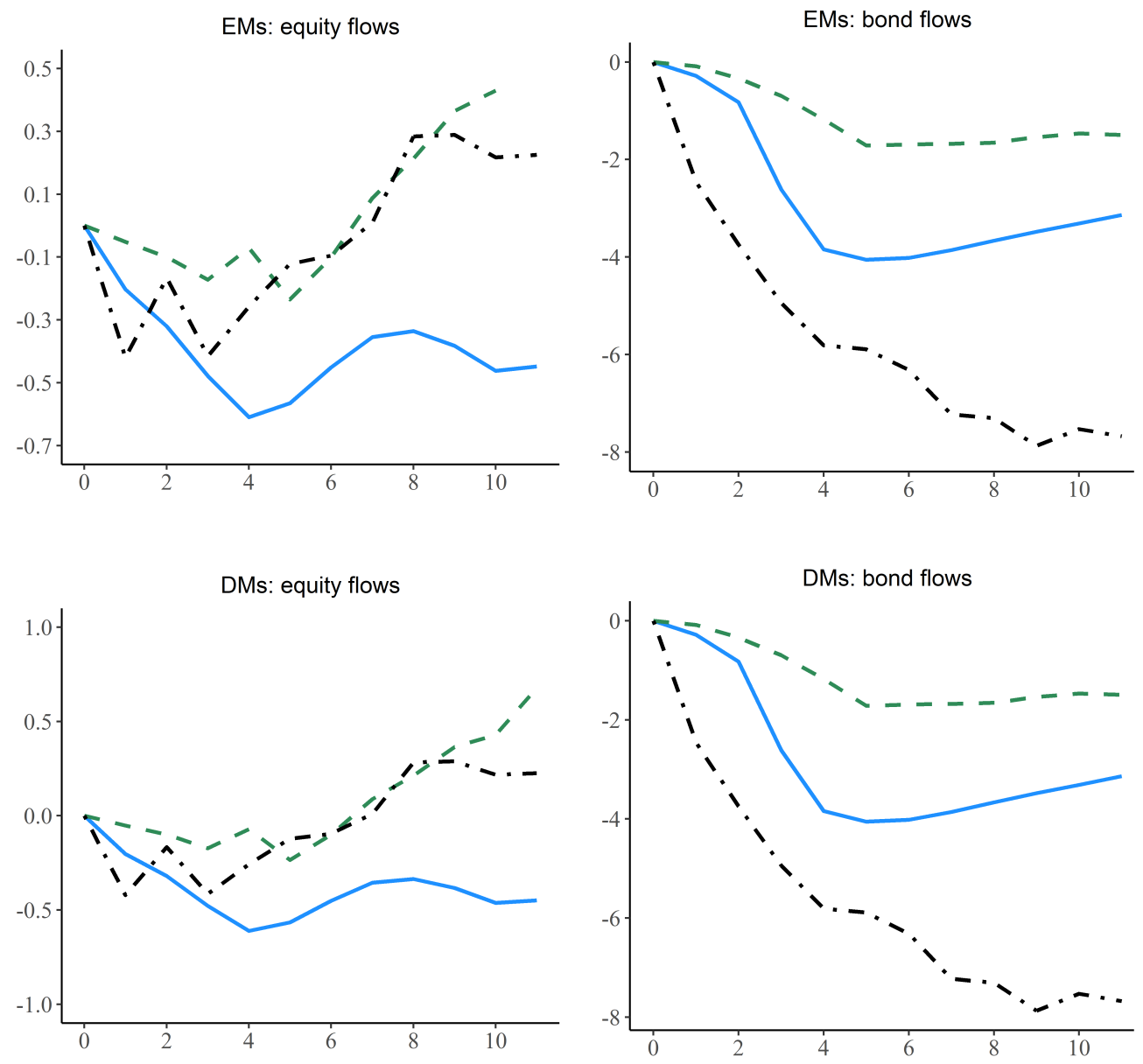

- COVID-19 - Taper tantrum - - GFC

Notes: x-axis shows weeks after the start date for the following episodes: COVID: 2020/02/26-2020/04/29; taper tantrum: 2013/05/22-2013/08/14; global financial crisis: 2008/10/08-2008/12/31. Flows are normalized by the allocation at the start of each episode. 